\title{
درجة ممارسة القيادة المدرسية لأدوارها في رعاية الطلبة الموهوبين بمحافظة جدة
}

فهد بن عبد الرحمن المالكي

أستاذ مشارك- كلية التربية

جادعة جدة- السعودية
محمد بن أحمد الشهري

مدير المدرسة الفيصلية للموهوبين- السعودية

Abolama766@gmail.com 


\title{
درجة ممارسة القيادة المدرسية لأدوارها في رعاية الطلبة الموهوبين بمحافظة جدة
}

\author{
محممد بن أحمد الشهري \\ مدير المدرسة الفيصلية للموهوبين- السعودية الهمبرية \\ Abolama766@gmail.com \\ فهد بن عبد الرحمن المالكي \\ أستاذ مشارك- كلية التربية- جامعة جدة- السعودية
}

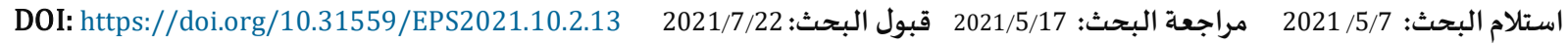

هدفت الدراسة إلى التعرف على درجة ممارسة القيادة المدرسية لأدوارها في رعاية الطلبة الموهوبين من وجهة نظر المعلمين، واتبعت الدراسة

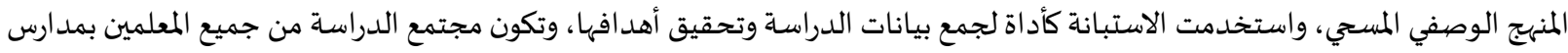

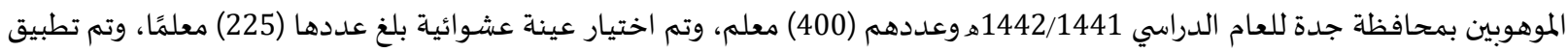

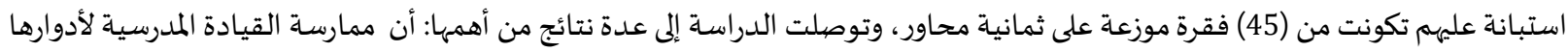

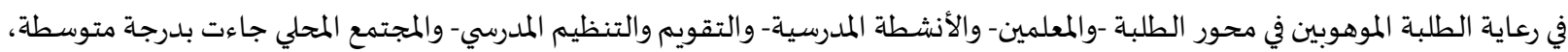

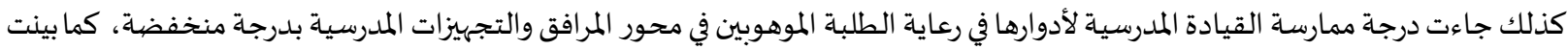

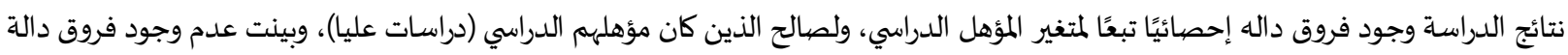
إحصائيًا تبعًا لمتغير نوع التخصص، ووجود فروق داله إحصائيا تبعًا لمتغير الدورات التدرببية في رعاية الموهوبين، ولصالح الذين تلقوا أكثر من 3 دورات

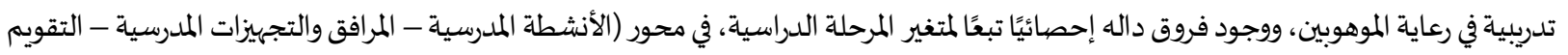

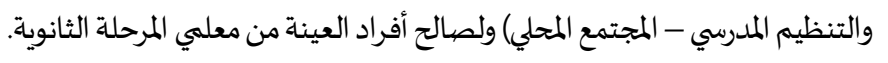
الكلمات المفتاحية : القيادة المدرسية؛ الموهوبين؛ الممارسة.

الطلاب الموهوبون هم أصحاب القدرات العالية بما حباهم الله من تميز وتفرد بين أقرانهم، ولذا فإن استثمارهم ورعايتهم والاهتمام بهم هو الطريق الأمثل لكي يعود عطاؤهم وثمار رعايتهم على مجتمعاتهم وأوطانهم بالنفع والتقدم. ونظرًا لأهميتهم في مواجهة تحديات العصر الذي نعيش فيه -عصر اقتصاد المعرفة والتطور المذهل في جميع الجوانب، والذي يعتمد على تخطي الحواجز

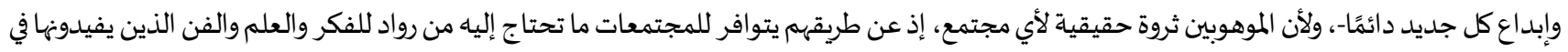

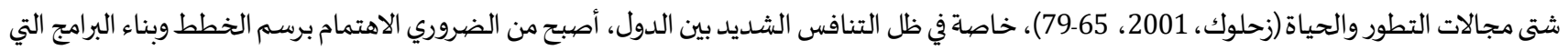

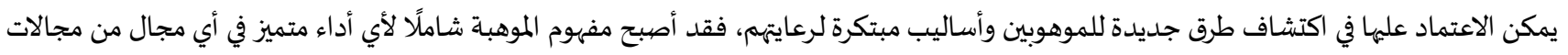
الحياة، بل تعدى المفهوم إلى القدرات الكامنة التي لم تبرز. (عناني، 2012) ويمثل الاهتمام بالموهوبين ضرورة حتمية حضارية يفرضها التحدي العلمي والتكنولوجي، ويُعد مطلبًا رئيسًا للتنمية البشرية ووسيلة فعّالة لتطوير المجتمع؛ 
مما يلقى العبء على النظام التعليمي بضرورة استثمار هذه الثروة البشرية من الموهوبين، وفى ظلل التحديات التي يواجها المجتمع في مجال المعلوماتية العلمية

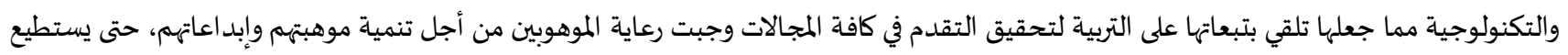

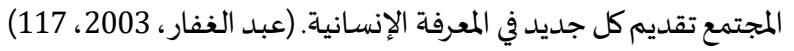

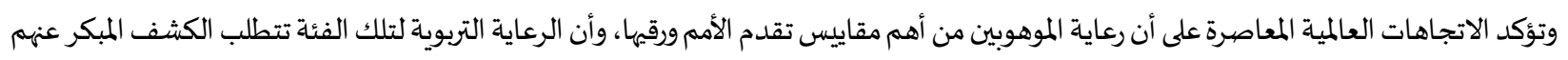

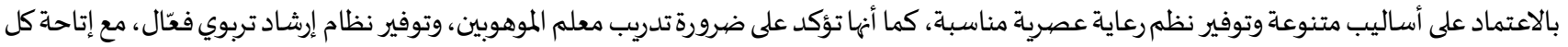

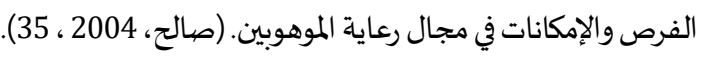

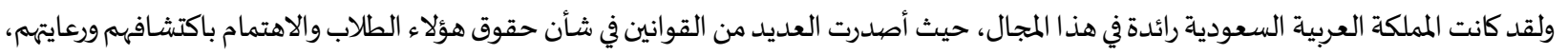

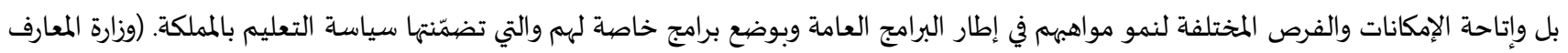

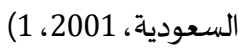

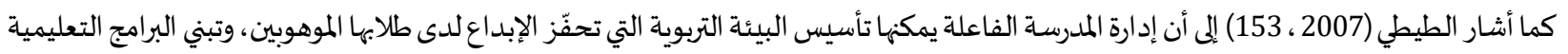

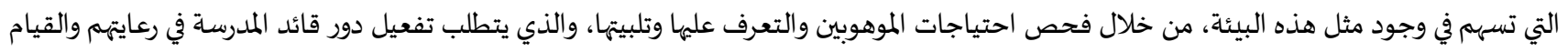

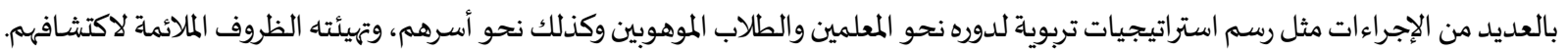

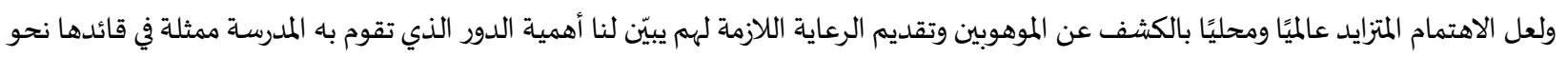

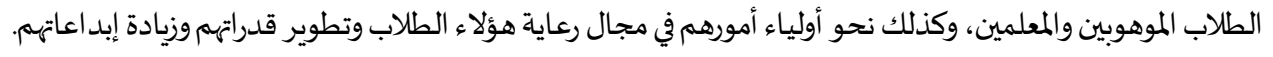

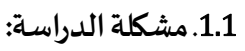

عمدت المملكة العربية السعودية إلى تبني أدوار تعمل من خلالها على استيعاب كافة المستجدات التي تمكنها من رعاية الموهوبين ووضع البرامج اللازمة لصهقل

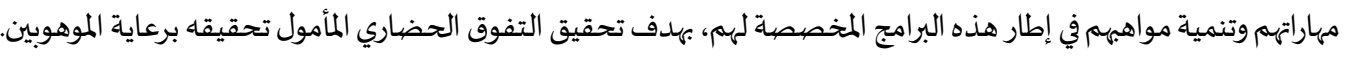

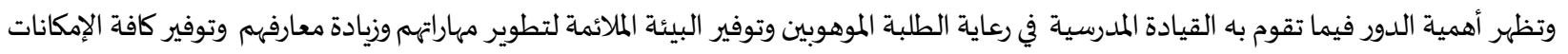

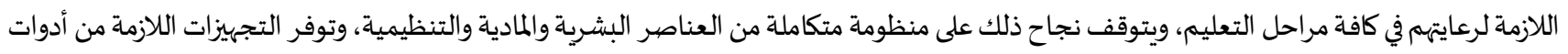

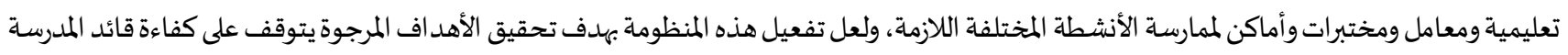

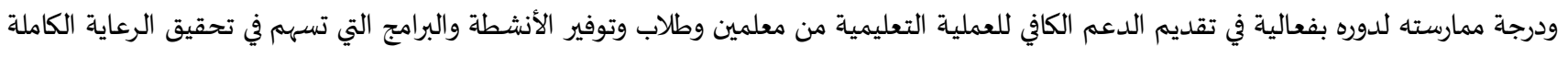

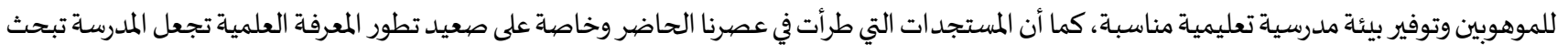

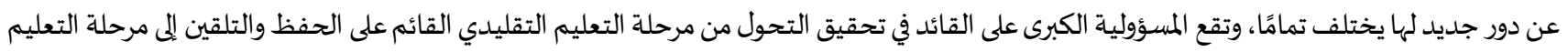
الإبداعي الذي يهدف إلى تنمية الموهوبين ورعايتهم.

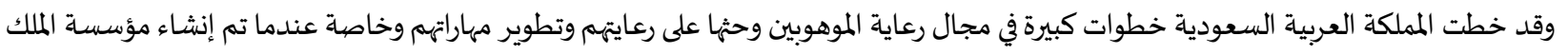

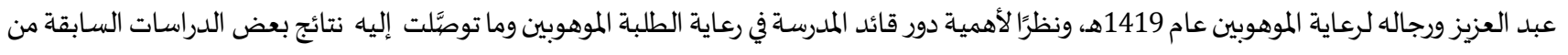

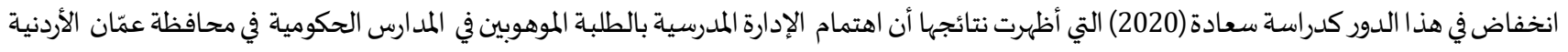

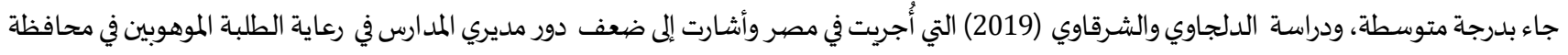

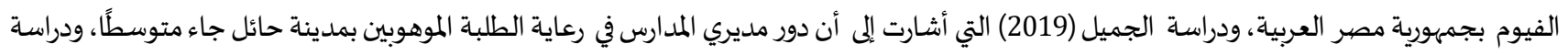

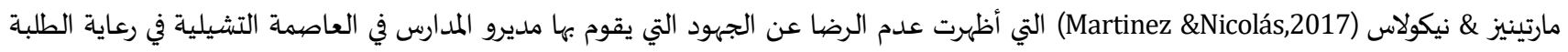

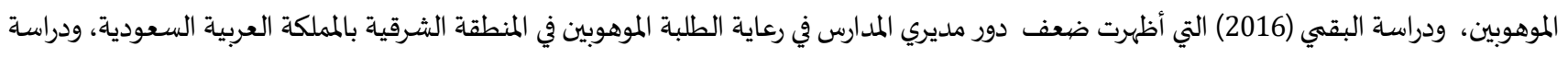

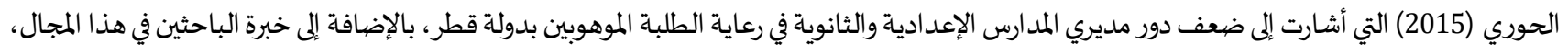

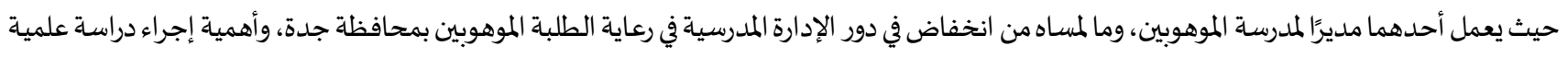

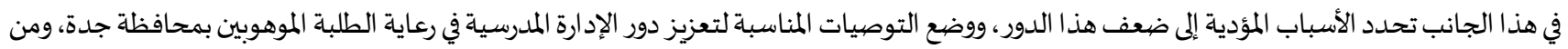

هنا ظهرت مشكلة الدراسة الحالية.

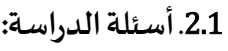

تسعى الدراسة للإجابة عن الأسئلة الآتية:

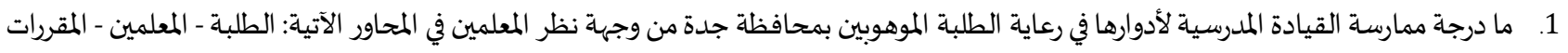

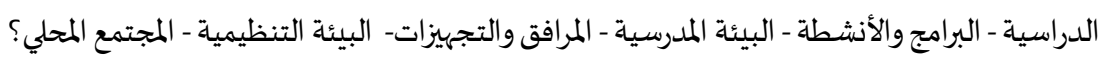

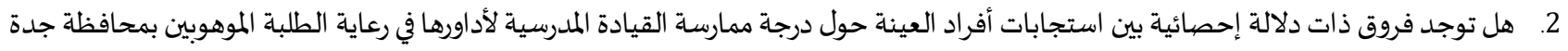

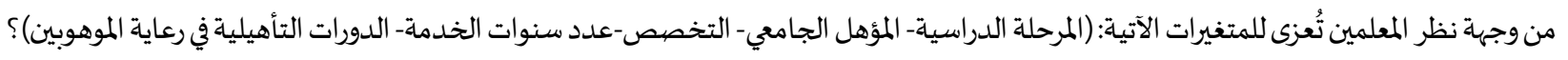


3.1 أهداف الدراسـة:

1. التعرف على درجة ممارسة القيادة المدرسية لأدوارها في رعاية الطلبة الموهوبين بمحافظة جدة من وجهة نظر المعلمين. 2. الكشف عمّا إذا كانت هناك فروق ذات دلالة إحصائية في استجابات أفراد العينة حول درجة ممارسة القيادة المدرسية لأدوارها في رعاية الطلبة

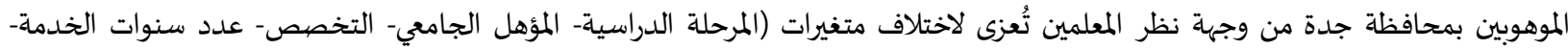
الدورات التأهيلية في رعاية الموهوبين).

4.1 أهمية الدراسـة: تكمن أهمية الدراسة الحالية فيما يلي: 1. أهمية الطلبة الموهوبين في المجتمعات، وما يمتلكونه من قدرات عقلية إبداعية متميزة تسهم في نمو المجتمع وتطوره. 2. 3. الاستجابة لتوصيات بعض الدراسات السابقة التي تحث على رعاية الموهوبين وتوفير البيئات التعليمية الملائمة لهم، مثل دراسة المطيري وسليمان (2020)، ودراسة الجميل (2019). 4. قد تسهم في تقديم بعض التوصيات التي تفيد في تطوير قادة المدارس للوصول بهم إلى الأداء المتميز في رعاية الطلبة الموهوبين. 5. استفادة بعض الأفراد والجهات ذات العلاقة من نتائج الدراسـة الحالية.

5.1

أُجريت الدراسة الحالية في ضود الماهدة المحددات الآتية: الحد الموضوعي: تقتصر الدراسة الحالية على معرفة درجة ممارسة القيادة المدرسية لأدوارها في رعاية الطلبة الموهوبين بمحافظة جدة من وجهة نظر المعلمين. الحد المكاني: طبقت الدراسة الحالية على مد ارس الموهوبين بمحافظة جدة بنين بمراحلها الثلاث (الابتد ائية والمتوسطة والثانوية). الحد البشري: تكونت عينة الدراسـة من معلمي الموهوبين (بنين) بمحافظة جدة. الحد الزمني: طبقت أُداة هذه الدراسة في الفصل الدراسي الثاني لعام 1442هـ معرسي 6.1. مصطلحات الدراسـة: القيادة المدرسية: عرّف الداعور (2007 ، 10) القائد المدرسي بأنه "الشخص الفعّال الذي يهتم بالتخطيط والتوجيه والمتابعة والتقويم للعمليات التعليمية، ولدياه القدرة على التأثير في الآخرين وإيجاد الحلول للمشكلات التي تواجه المدرسة لتحقيق الأهداف التربوية". ويُعرف إجرائيًا بأنه: القائد المكلّف من قبل إدارة التعليم وهيتم بإدارتها بطريقة تتفق مع توجهات السياسة العامة والنظم واللوائح المنظّمة للعمل داخل الوزارة، ويعمل على تحقيق الأهداف التعليمية والتربوية المحددة. •

عرفه تنيره (2016، 7) بأنه: "مجموعة من المهام والواجبات التي يساهم بها مدير المدرسة لاكتشاف الطلبة الموهوبين ورعايتهم من خلال توظيف النشاطات الهادفة". ويُعرف إجرائيًا بأنه: مجموعة من الجهود المبذولة التي يقوم بها قائد المدرسة مع جميع العاملين من المعلمين والإداريين وغيرهم في مجال اكتشاف ورعاية الطلاب الموهوبين من أجل تحقيق الأهداف التربوية للمدرسة تحقيقًا يتمشى مع مايهدف إليهاء المجتمع من تربية صحيحة لهؤلاء الطياء الطلاب. الطالب الموهوب: عرفه العاجز ، ومرتجي (2012، 337) بأنه: الطالب الذي لديه قدرات خاصاة تؤهله للتفوق في مجالات معينة: علمية أو أدبية أو فنية، وغيرها، وتجعله قادرًا

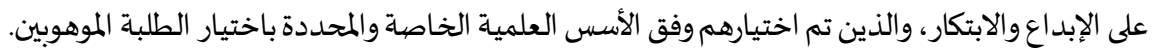

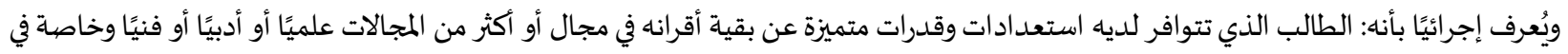

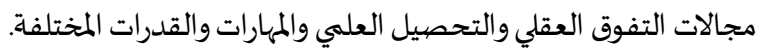
2. الإطار النظري والدراسـات السـابقة تُعد القيادة المدرسية الأساس الذي تعتمد عليه المؤسسات التربوية في تقدهها، وبغيره لا يمكن أن تحدث أي نقلة فعلية، أو إصلاحح حقيقيّ داخل المؤسساة، 
فالقيادة المدرسية تتعامل مع أفراد مختلفي الثقافات، ومتعددي الاتجاهات، وهذا يتطلب القدرة على التعامل، بغض النظر عن اختلاف الأفراد مع ضرورة تنسيق

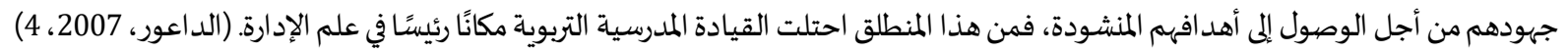

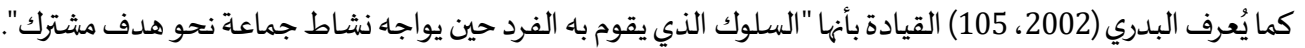

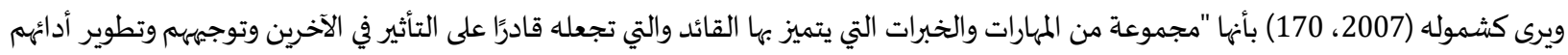
ومساعدتهم على التخلص من العقبات التي تصادفهم في علاقاتهم وأعمالهم من أجل تحقيق الأهداف المشتركة".

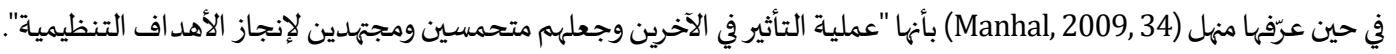
وبذلك فالقيادة المدرسية تؤدى دورًا بارذًا في العملية التعليمية فهي تعتبر وسيلة مهيمة لتنظيم الجهود الجماعياة في المهاية المدرسة سعيًا في تنمية الطالب تنمية

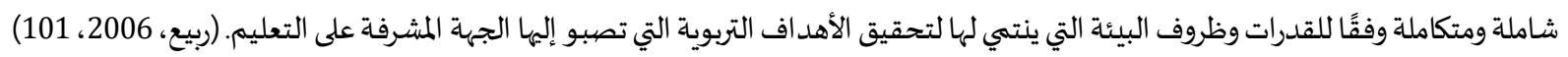
ويتضح مما سبق من تعريفات للقيادة المدرسية أهمية القائد المدرسي ودوره في تحقيق أهداف المؤسسة التربوية والتعليمية.

2.2. 20 20 مفهوم الطالب الموهوب: تعددت التعريفات التي تناولت مفهوم الطالب الموهوب، ومن أهمها ما يلي:

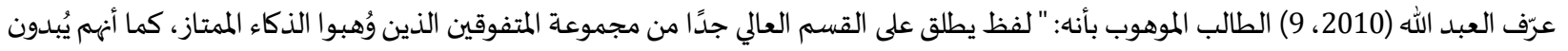
سمات معينة تجعلنا نعقد عليهم الأمل في الإسهام بنصيب وافر عميق في فيله جيلهم". بينما عرّف السدة (2012، 20) الطالب الموهوب بأنه: "صاحب الأداء المتقدم الاستثنائي أو القدرة الكامناة على الأداء المتميز فيما يختص بالهالئه بالذكاء، أو الإبداع، أو القيادة، أو الفنون، أو مجالات أكاديمية محددة، حيث يأتي الطلبة ذوو المواهب المتميزة من جميع البيئات الاجتماعية والثقافية والاقتصيادية". بينما عرّف الهاشمي (2014، 18) الطالب الموهوب بأنه: ذلك الفرد الذي يُظهِر أداءً متميزًا، مقارنة مع المجموعة العمرية التي ينتهي إلهها في واحدة أو أكثر من الأبعاد التالية: القدرة العقلية العالية، القدرة الإبداعية العالية في أي مجال من مجالات الحياة، القدرة على التحصيل الأكاديمي المرتفع، والقدرة على القيام بمهارات متميزة، أو مواهب متميزة. ومما سبق يتضح أن الطالب الموهوب هو ذلك الفرد الذي يظهر قدرة عقلية عالية، وقدرة على الإبداع، والتزامًا بأداء المهارات المطلوبة منه.

3.2. خصيائص الموهوبين: تتعدد خصائص الموهوبين من جوانب عدة هي: الخصيائص العقلية والمعرفية:

وتتمثل الخصائص العقلية والمعرفية في القدرة على الحفظ والاستيعاب لكمٍّ كبير من المعلومات (قوة الذاكرة)، والقدرة على الفهم المتقدم، وحب الاستطلاع والاكتشافات، وتنوع الاهتمامات، وارتفاع مستوى النمو اللغوي، والقدرة على تناول المعلومات، ومرونة التفكير، والتجميع الشمولي للمعلومات والأفكار، وارتفاع

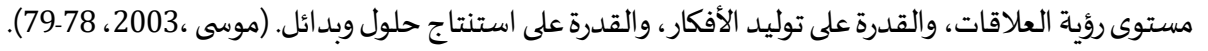
الخصائص الاجتماعية والانفعالية: يشير البريك (2010، 31-31) للخصائص الاجتماعية والانفعالية فيما يلي: تحمُّل المسؤولية والاهتمام بقضايايا الآخرين، والقدرة العالية على القيادة

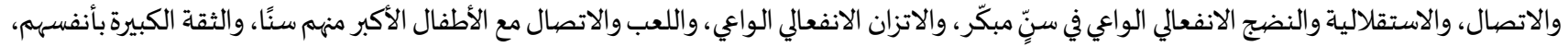

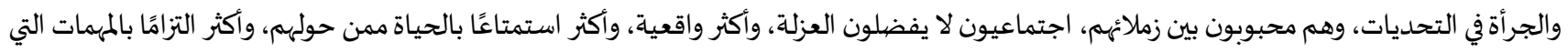

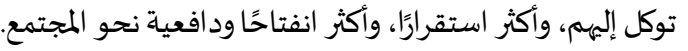

م الخصائص الجسمية: حدد جروان (2013، 27) الخصائص الجسمية، فيما يلي: أكثر طولًا ووزنًا من الأطفال العاديين، والصحة البدنية حيث يكونون أقل عرضية للأمراض من الأطفال العاديين، والمشي في سن مبكر، والنوم فترات قليلة.

الخصبائص الإبداعية:

يحدد موسى (2003) الخصائص الإبداعية، فيما يلي: القدرة العالية على الخيال، والحساسية العالية من المشكلات، والأصالة العالية في التفكير، والتفكير بأكثر من حل للمشكلات، والتصرف بحكمة عند المشكلات، وهم على قدر عالٍ من حب اكتشاف الغموض، ومفكرون لديهم القدرة على الإبداع والربط بين

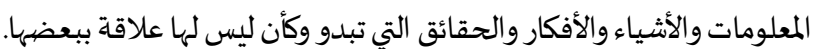
ومما سبق يتبين أن هذه الصفات والخصائص لا تظهر كلها مجتمعة وعلى الوالدين ملاحظتها في المنزل أثناء ممارستهم للعب الهوايات والأنشطة الأسرية، ويمكن للمعلمين ملاحظتها أثناء اليوم الدراسي والأنشطة المختلفة داخل المدرسة وخلئ وخارجها. 
4.2 أنواع الموهبة:

ترى الدراسة أن تحديد الموهبة العامة أو الخاصةة قد يزيل بعض التداخل والالتباس عند الكثيرين، وذلك كما يراها (شقير، 1998) على النحو الآتي: الموهبة العامة: هي مستوى عالٍ من الاستعداد والقدرة (العامة) على التفكير المتجدد والأداء الفائق في (أي مجال) -له قيمة- من مجالات النشاط

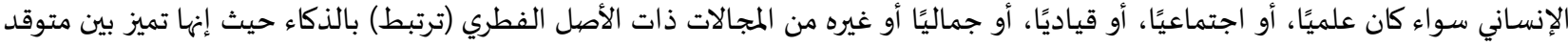

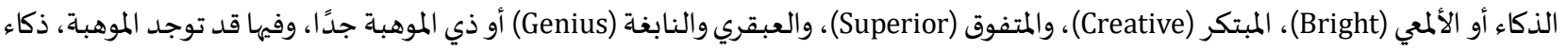

$$
\text { الموهبة ابتكار، الموهبة التحصيل ... إلخ. }
$$

الموهبة الخاصةة: هي مستوى عالٍ من الاستعداد والقدرة (الخاصة)على الأداء المتميز في (مجال معين) وأكثر من مجالات النشاط الإنساني، وهي ذات

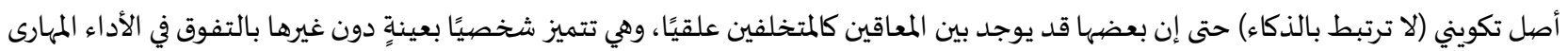

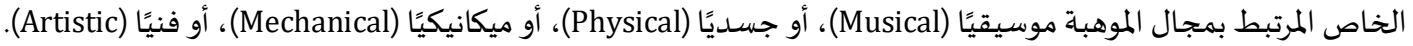

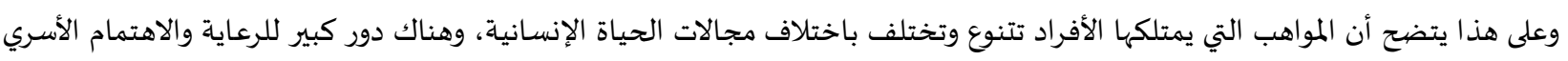
والمدرسي في صقل هذه المواهب وبروزها.

5.2. سمات الموهوبين:

أبرز سمات الطلاب الموهوبين ما يلي:

أولًا: السمات التعليمية:

حدد الزامل (2014) السمات التعليمية للطلاب الموهوبين في المملكة العربية السعودية فيما يلي:

$$
\text { يميل الموهوب إلى التفوق وحب المناقشاة. }
$$

لدياء حصيلة كبيرة من المعلومات عن موضوعات شتى.

لدياه القدرة على إدراك العلاقات السببية بين الأشياء.

لا يمل من العمل المستمر ولديه القدرة على تركيز الانتباه لمدة أطول من العاديين.

ثانيًا: السمات الدافعية:

حدد الهاشمي (2014) السمات الدافعية للطلاب الموهوبين في المملكة العربية السعودية فيما يلي:

غالبًا ما يكون متعصبًًا لرأيه وعنيدًا.

يستطيع أن يكتشف الخطأ ويميز بين الخطأ والصواب والحسن والسيئ.

يهتم بأمور الكبار التي لا يبدي مَن هو في سنه أيَّ اهتمام بها.

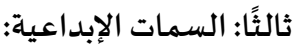

حدد السدة (2012) السمات الإبداعية للطلاب الموهوبين في المملكة العربية السعودية فيما يلي:

$$
\text { • يحب الاستطلاع ودائم التساؤل. }
$$

يحاول إيجاد أفكار وحلول لكثير من المسائل.

يتمتع بسعة الخيال وسرعة البديهة.

لا يخشى الاختلاف مع الآخرين.

يتمتع بروح الفكاهة والدعابة.

رابعًا: السمات القيادية:

حدد الزامل (2014) السمات القيادية للطلاب الموهوبين في المملكة العربية السعودية فيما يلي:

$$
\text { • كف في تحمّل المسؤولية وينجز ما يوكل لله. }
$$

ذو ثقة كبيرة بنفساه ولا يخشى من التحدث أمام الجمهور.

$$
\text { محبوب بين زملائه. }
$$

لدياء القدرة على القيادة والسيطرة.

يشارك في معظم الأنشطة المدرسية والاجتماعية.

ومما سبق يتبين أن الطلاب الموهوبين هم الطلاب الذين يتصفون بالقدرة على أداء متميز في مجال القدرات الإبداعية والفنية والقيادية أو في 
مجالات دراسية محددة، وهؤلاء الطلاب الذين يملكون قدرات وإمكانات غير عادية تبدو في أدائهم العالي والمتميز والذين يتم تحديدهم من خلال خبراء

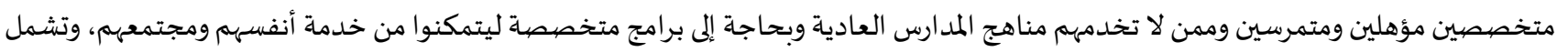

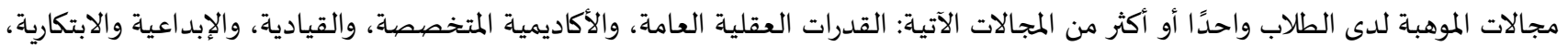

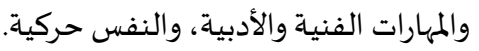

6.2. دورقائد المدرسة في رعاية الموهبة: من المؤكد أن الدور الذي تلعبه الإدارة المدرسية المتمثلة في قيادتها المدرسية في توفير المناخ التربوي الداعم للكشف عن عن الموهوبين ورعايتهم وتنميتهم مبكرًا يعد في غاية الأهمية، وسوف يكون لها دور في تنمية المجتمع بشكل عام، وانطلاقًا من ذلك الدور الكبير في العملية التعليمية والتربوية

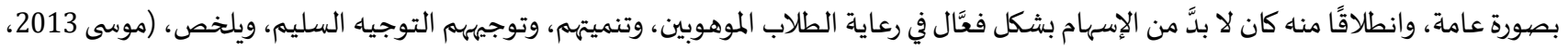

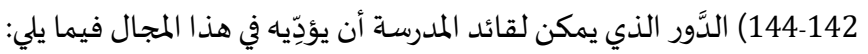
وضيع خطة لرعاية الطلاب الموهوبين وتدارسها مع زملائه المعلمين في مجلس رعاية الموهوبين، ووضعها موضع التنفيذ خلال العام الدراسي، ومتابعتها بدقة وعناية، وتتضمن حصر المواهب وما سُيقدّم للموهوبين.

الإِّلاع على كل جديد في هذا المجال؛ لإفادة طلابه الموهوبين، وتشجيعهم، وتحفيز الهمم لديهم لاستمرار وتنمية تلك المواهب التي منحها الخالق سبحاناه وتعالى-بعض الطلاب. توفير الجوّ التربوي الملائم لنموِّ الموهبة، وإشعار الطلاب الموهوبين بمكانتهم وأهميتهم، وأههم أمل الأمة في مستقبل مشرق، وذلك من خلال عقد

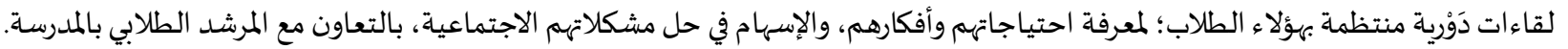
توفير الأدوات والتجهيزات، وأماكن ممارسة الأنشطة لمعرفة المواهب وتنميتها وتطويرها.

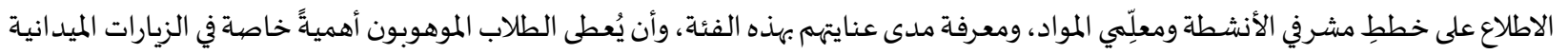

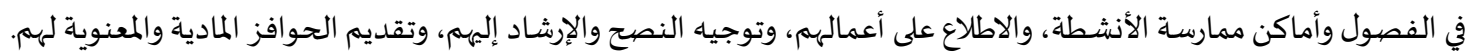
وضيع خطة تتضمن تدريب المعلِّمين على كيفية التعامل مع الطلاب الموهوبين، وفتح قنوات للاتصال مع المشرف التربوي، والمسؤولين في إدارة التعليم عن رعاية الموهوبين، وتزويدهم بالتقارير اللازمة والاحتياجات؛ لتوفير ما يمكن توفيره من إمكانات بشرية ومادية، من أجل النهوض بالطلاب الموهوبين والحفاظ على مواهبهم. الاتصال بأولياء الأمور، وتعريفهم بمواهب أبنائهم ليتحقق التكامل بين دور الأسرة ودور المدرسة في رعايتهم.

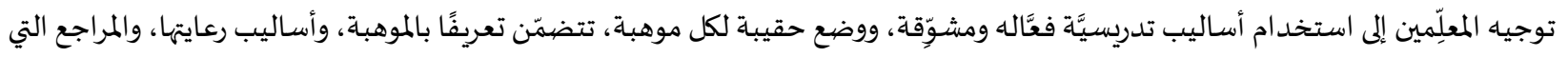

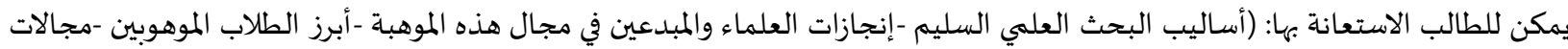
التخصص وفرص العمل -كيفية الاستفادة من مصادر التعلم والبحث). توجيا الرائد الاجتمائي إلى وضِع خطة للمسابقات العلمية والثقافية، والزيارات والرحلات، والمعسكرات الفنية والعلمية، وتنفيذها بكل دقةة،

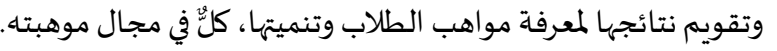
تفعيل دور الإعلام التربوي بالمدرسة، وأن يكون في كل مدرسة نشرة دوريَّة تربوية، تتضمن إنتاج الموهوبين وأخبارهم ومنجزاتهم على مستوى المدرسة والإدارة التعليمية. إقامة المعارض العلمية والفنية والأمسيات الأدبية وغيرها من مختلف المواهب، على مستوى المدرسة والإدارة التعليمية، ودعوة المسؤولين وأولياء الأمور؛ للرفع من معنويات الطالب الموهوب وإبراز موهبتهاء

7.2 الدراسـات السـابقة:

دراسة المطيري، وسليمان (2020)، هدفت الدراسة المى التعرف على دور الإدارة المدرسية في رعاية الموهوبين من خلال تفعيل دور المعلمفي المرحلة المتوسطة، كما هدفت للتعرف على دورها في رعايتهم بتلك المرحلة والوقوف على أهم المعوقات التي تقلل من إسهامها في رعايتهم، بهدف التوصل إلى مقترح لتفعيلها، ولتحقيق أهداف داف

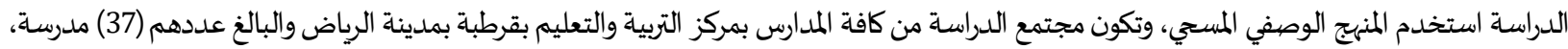

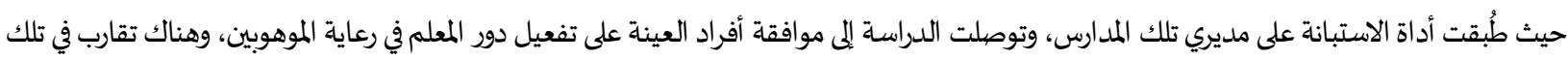
الموافقات بين أفراد العينة، بل جاءت موافقتهم على وجود معوقات تسهم في القيام بدورهم وتقلل من رعايتهم للموهوبين بمدارسهم بالمرحلة المتوسطة، وتوصى معيى الدراسة بالعمل على التنسيق بين معلمي الموادومعلم غرفة الصفف في تقديم الخدمات التربوية للطلاب الموهوبين، وتوفير برامج تدريبة تواجه المدربين والمعلمين بشأن رعايتهم للموهوبين. 
دراسة سعادة (2020)، هدفت الدراسة إلى الكشف عن درجة اهتمام الإدارة المدرسية بالطلبة الموهوبين من وجهة نظر مديري ومديرات المدارس الحكومية في لواء

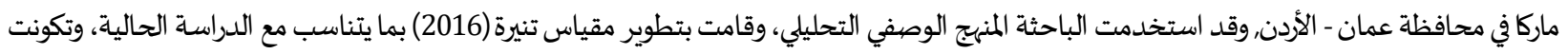

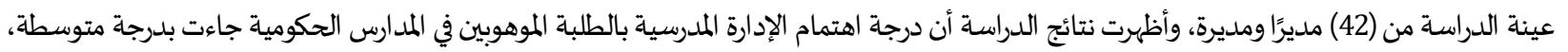

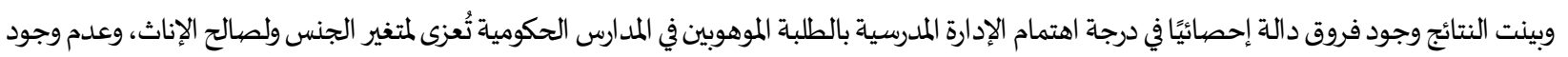

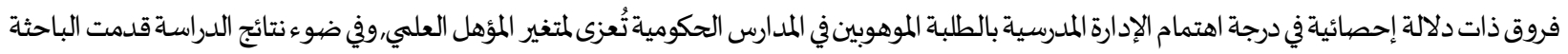

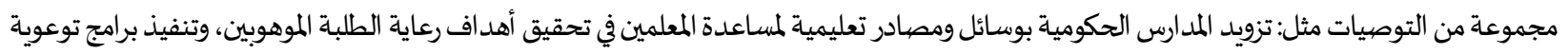

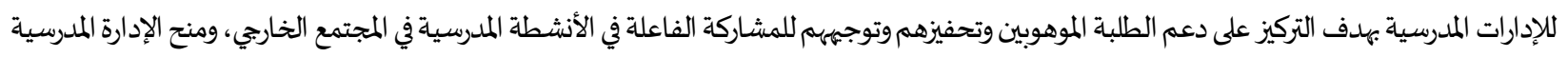

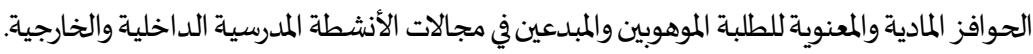

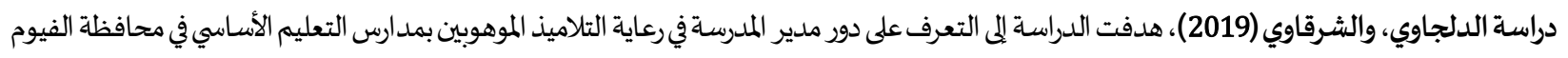

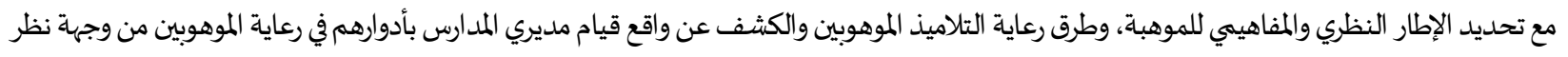

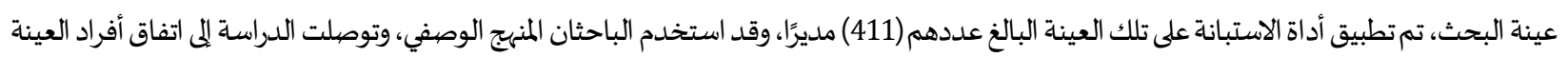

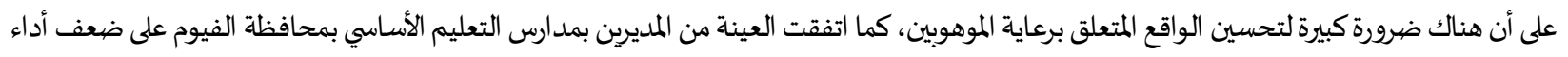

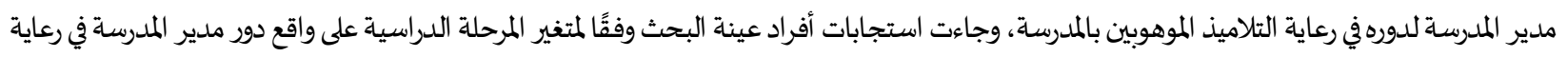

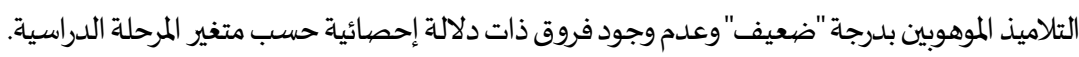

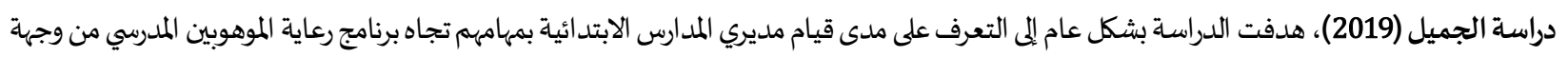

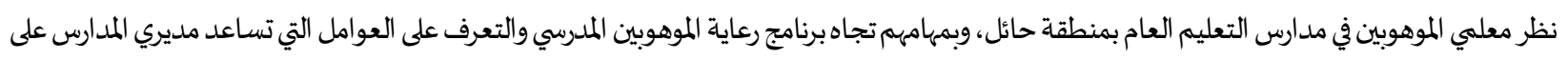

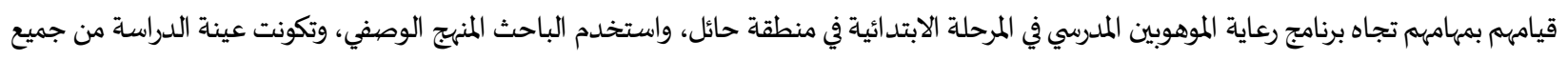

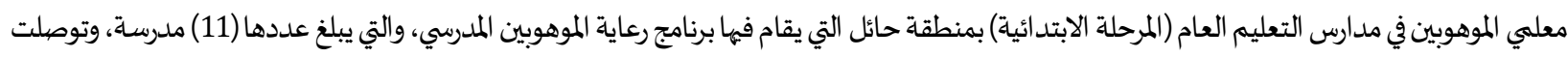

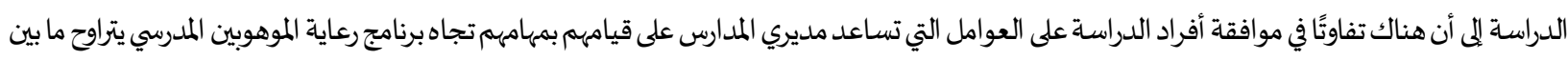

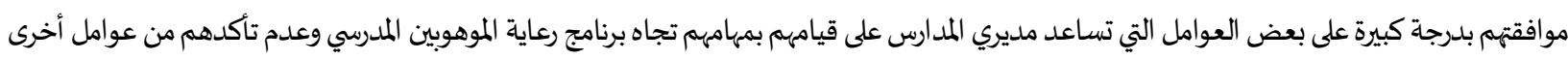

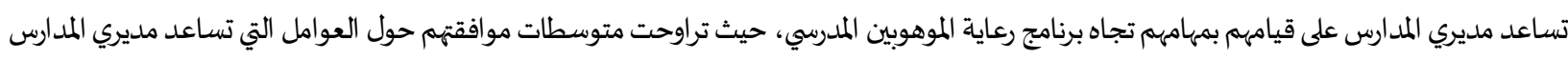

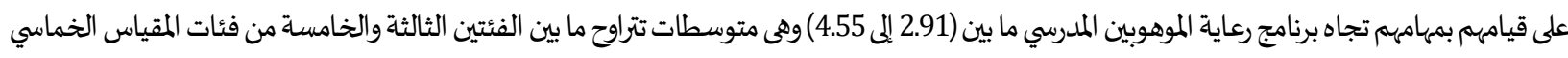

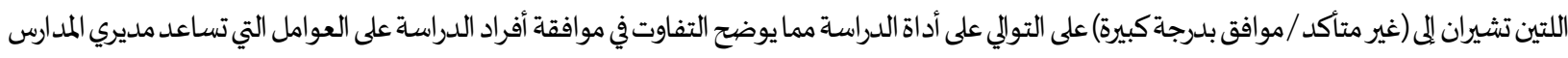

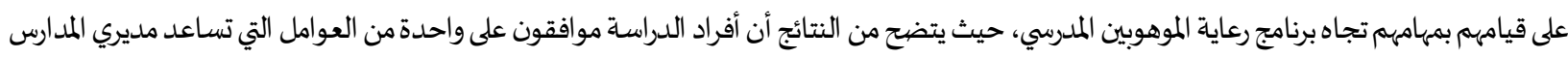

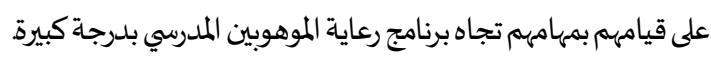

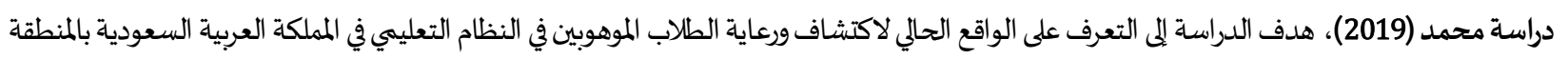

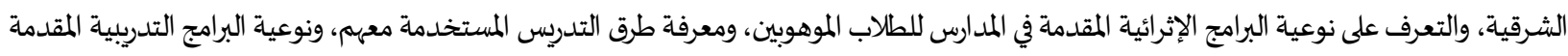

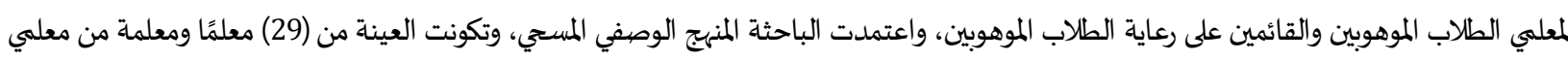

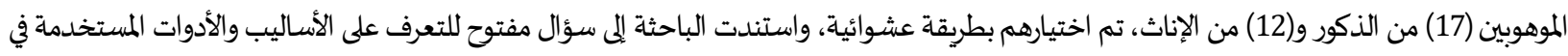

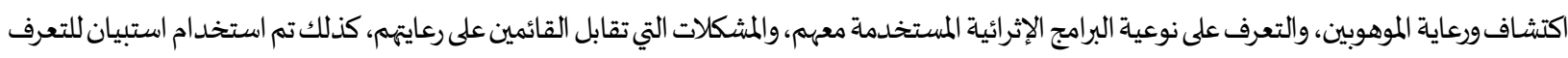

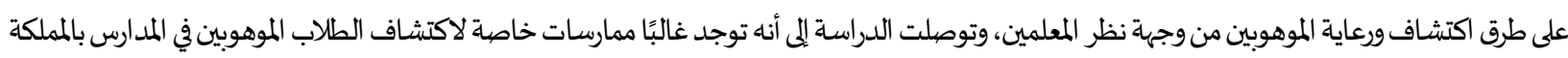

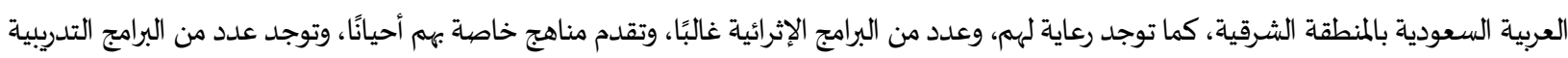

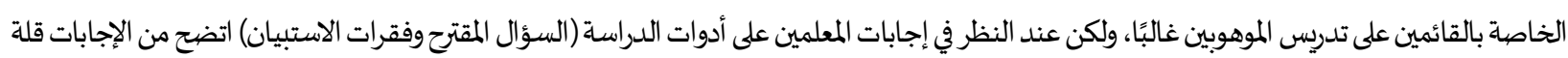

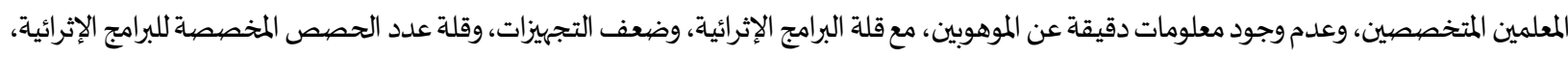

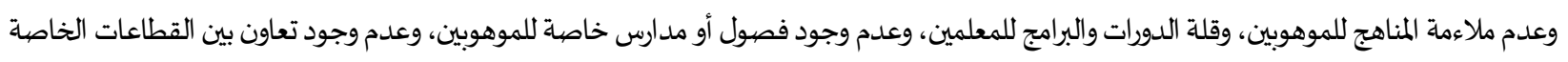

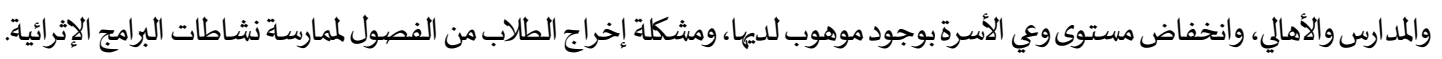

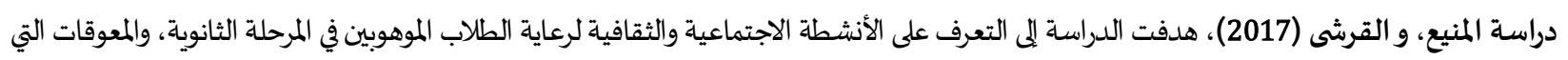

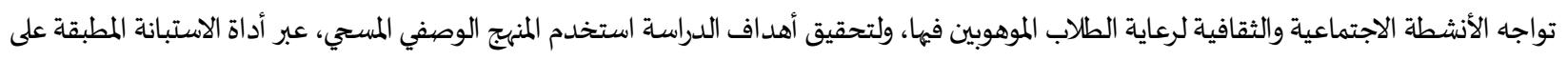

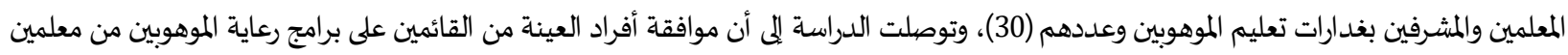

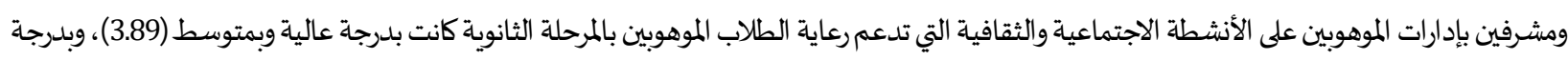
عالية على المعوقات التي تواجه الأنشطة الاجتماعية والثقافية لرعايتهم بدرجة متوسطة (4.14)، وبدرجة عالية جادئا على الماعلى المقترحات لتطوير الأنشطة الاجتماعية 
والثقافية لرعاية الطلاب الموهوبين بالمرحلة الثانوية.

دراسة مارتينيزع نيكولاس (Martinez \&Nicolás,2017)، هدفت الدراسة المى التعرف على مدى اكتشاف ورعاية مدارس العاصمة التشيلية لقدرات ومواهب الطلاب وتنميتها، والتعرف على الاجراءات والإستراتيجيات المتبعة لاكتشاف الموهوبين ورعايتهم في المدرسة، واستخدم الباحث المنهج الوصفي التحليلي، مطبقًا أداة

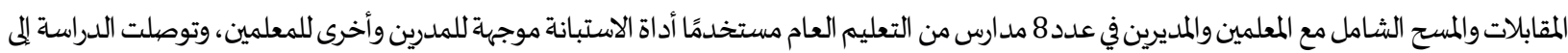

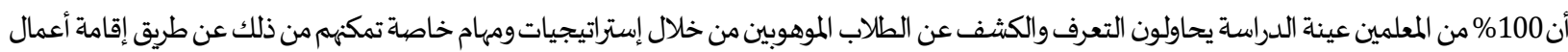
الموهوبين وإبد اعاتهموخاصة معارض علمية (86\%)، وعقد الأولمبياد (71\%)، ووضع خطط خاصةة وعقد اجتماعات مع أولياء الأمور وأفراد الإدارة المدرسية (83\%) )،

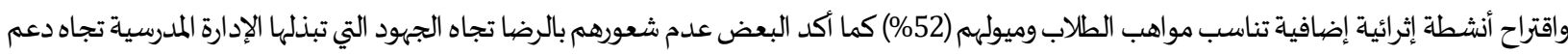
وتعزيز المواهب، وأن هناك ميلاً واضحًا للاعتراف بالطالب الموهوب واستعداد إنساد المعلمين لتعزيز هذه المواهب وتنميتها بالرغم من عدم تقديم الدعم الكافي من المدرسة. دراسة البقهي (2016)، هدفت الدراسة المى التعرف على درجة ممارسة مديري المدارس المطبقة لبرامج رعاية الموهوبين لدورهم الإداري من وجهة نظر معلمي الموهوبين، وكذلك التعرف على المعوقات التي تعيق قيامهم بأدوارهم، بالإضافة إلى التعرف على المقترحات اللازمة لتفعيل أدوارهم، واتبعت الدراسة المنهج الوصيفي وطبقت استبانة على عينة من معلمي الموهوبين بالمدارس المطبقة لبرامج رعاية الموهوبين، وتوصلت الدراسة إلى أن معلمي الموهوبين يوافقون على ممارساتيات المباتيات المديرين

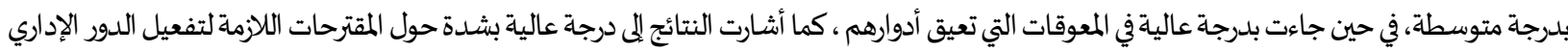

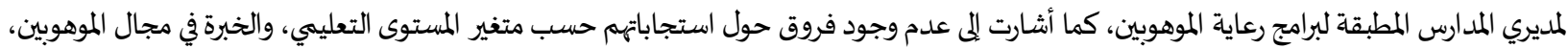

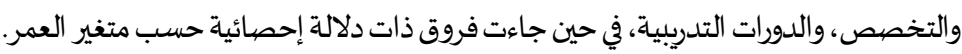
دراسة الحوري(2015)، هدفت الدراسة إلى التعرف على دور مديري المدارس الإعدادية والثانوية في رعاية الطلبة الموهوبين من وجهة نظر المعلمين في دولة قطر، وهل توجد فروق ذات دلالة إحصائية في استجابات المعلمين لدور مديري المدارس في رعاية الطلبة الموهوبين تُعزى لمتغيرات الجنس والمرحلة الدراسية والخبرة، واستخدمت الدراسة المنهج الوصفي التحليلي، وتكونت عينة الدراسة من (415) معلمًا ومعلمة تم اختيارهم بالطريقة العشوائية، وتم استخدام الاستيات الاستبانة كأداة

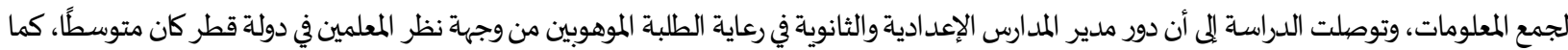
توصى الدراسة بضرورة إشراك المديرين في برامج تدريبية تُعنى باكتشاف ورعاية الموهوبين من الطلبة. دراسة أبو ناصبر (2014)، هدفت الدراسة إلى التعرف على درجة ممارسة مديري المدارس الحكومية ومديراتهافي المنطقة الشرقية لإدارة البرامجوالأنشطة المدرسية المتعلقة بالطلبة الموهوبين في ضوء متغيرات الجنس، والمؤهل العلمي، واشتملت عينة الدراسة على (219) مديرًا ومديره للمرحلة الابتدائية، طُبقت علهيهم استبانة

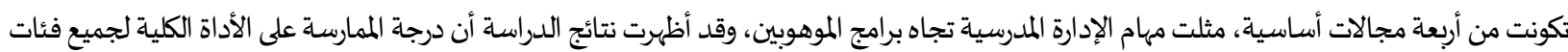

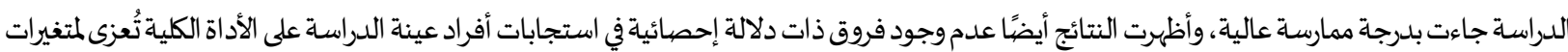

دراسة كريسي وإلينا (Elina\&Kirsi,2013) ، هدفت إلى استعراض طرق رعاية الطلبة الموهوبين المتبعة في المدارس بفنلندا؛ حيث تم استعراض البحوث التجرببية

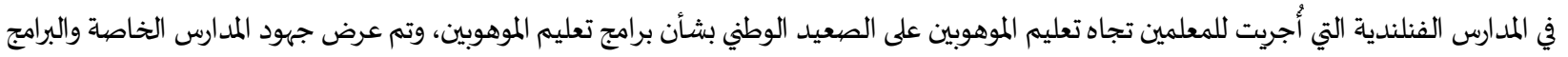

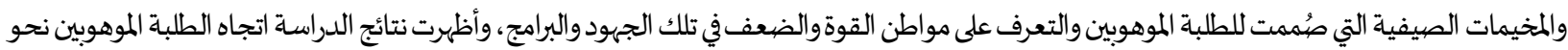

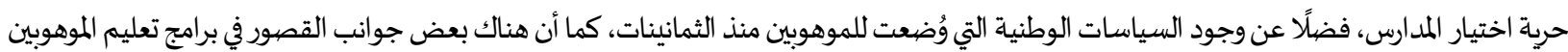

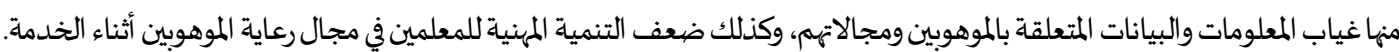
دراسة عناني (2012)، هدفت الدراسة إلى التعرف على المتطلبات التربوية لتفعيل دور مدير المدرسة بمرحلة التعليم الأساسي في اكتشاف ورعاية التلاميذ الموهوبين في ضوء تشريعات دولة الإمارات العربية المتحدةوالاتجاهات العالمية المعاصرة، واستخدمت الدراسة المنهج الوصفي التحليلي، وطبقت استبانة على عينة من مديري ومديرات مد ارس التعليم الأساسي الحكومية في منطقة العين التعليمية بإمارة أبو ظبي بدولة الإمارات العبية المتحدة والبالخ عددهئم (45) مديرًا ومديرة,

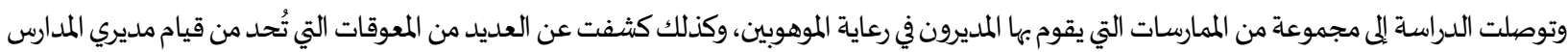

بدورهم في رعاية الموهوبين. التعليق على الدراسـات السابقة:

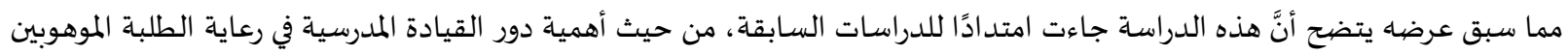
وتوفير البيئة الملائمة لتطوير مهاراتهم وزيادة معارفهم وتوفير كافة الإمكانات اللازمة لصقل مواهبهم, وذلك لأهمية الطلبة الموهوبين في المجتمعات، وما

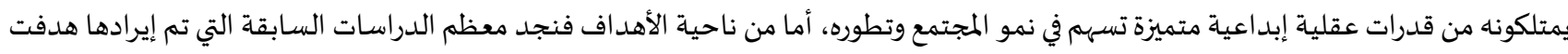
إلى التعرف على دور الإدارة المدرسية في رعاية الطلبة الموهوبين وتنمية مواهبهم, كذلك أظهرت نتائج بعض الدراسات السـابقة وجود تفاوت في دور القيادة

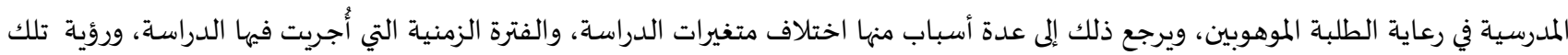

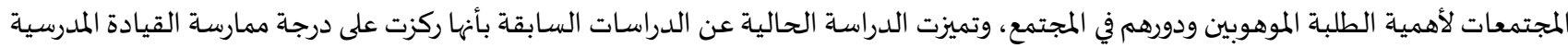




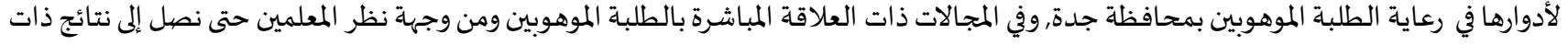

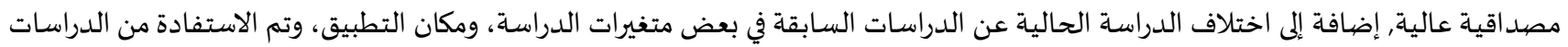
السابقة في إثراء الإطار النظري، والمساهمة في بناء أداة الدراسة، وتحديد محاورها ومتغيراتها، وتفسير بعض نتائيج الدراسة الحالية في ضوء نتائج بعض ون الدراسات السابقة.

3. منهجية الدراسة وإجراءاتها

1.3. منهج الدراسة:

اتبعت الدراسة الحالية المنهج الوصفي المستي، لمناسبة هذا المنهج لطبيعة الدراسـة، وتحقيق أهدافها.

2.3. مجتمع وعينة الدراسـة:

تكون مجتمع الدراسة الحالية من جميع المعلمين بمدارس الموهوبين بمحافظة جدة، والبالغ عددهم (400) معلم، موزعين على مد ارس مدينة جدة للعام الدراسي 1442/1441ه، واستجابت منهم عينة بلغت (225) معلمًا، والجدول التالي يوضح توصيف عينة الدراسـة وفقًا للمتغيرات المستقلة.

\begin{tabular}{|c|c|c|c|}
\hline 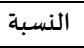 & 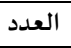 & فئات المتغير & المتغير \\
\hline$\% 30.7$ & 69 & ابتدائي & المرحلة الدراسية \\
\hline$\% 33.3$ & 75 & متوسطة & \\
\hline$\% 36.0$ & 81 & ثانوي & \\
\hline$\% 100$ & 225 & المجموع & \\
\hline$\% 70.7$ & 159 & بكالوريوس & المؤهل العلمي \\
\hline$\% 29.3$ & 66 & دراسات عليا & \\
\hline$\% 100$ & 225 & المجموع & \\
\hline$\% 52.0$ & 117 & أدبي & التخصص \\
\hline$\% 48.0$ & 108 & 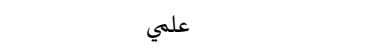 & \\
\hline$\% 100$ & 225 & المجموع & \\
\hline$\% 8.0$ & 18 & أقل من 5 سنوات & عدد سنوات الخدمة \\
\hline$\% 40.0$ & 90 & من 5 سنوات إلى أقل من 10 سنوات & \\
\hline$\% 52.0$ & 117 & 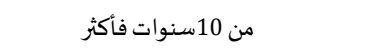 & \\
\hline$\% 100$ & 225 & المجموع & \\
\hline$\% 61.3$ & 138 & أقل من 3 دورات & عدد الدورات التدريبية \\
\hline$\% 38.7$ & 87 & 3 دورات فأكثر & في مجال رعاية الموهوبين \\
\hline$\% 100$ & 225 & المجموع & \\
\hline
\end{tabular}

3.3. أداة الدراسـة:

تم تصميم أداة للدراسة عبارة عن استبانة تكونت من جزئين، الأول: يتضمن البيانات الأولية لأفراد عينة الدراسة، ويشمل المتغيرات التالية:

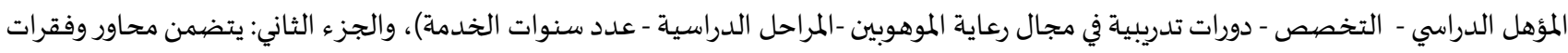

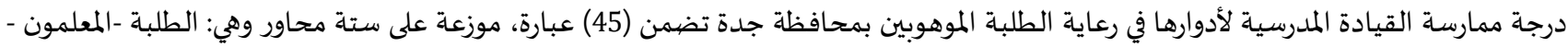

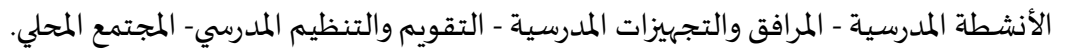
4.3 صبدق أداة الدراسـة: تم اتباع عدة إجراءات للتأكد من صداء ادهاء أداة الدراسة ومنها: الصيدق الظاهري:

للتحقق من الصدق الظاهري لأداة الدراسة تم عرضها بعد تصميمها في صورتها الأولية على عشرة من أعضاء هيئة التدريس ذوي الخبرة في مجال رعاية الموهوبين لإبداء الملاحظات حولها، وتم تعديل الاستبانة بما يتوافق مع الملاحظات والتوجيهات الإيجابية التي اتفق عليها أكثر المحكمين. الصيدق البنائي:

للتحقق من الصددق البنائي لأداة الدراسة تم استخدم معامل الارتباط بيرسون، وذلك لقياس درجة ارتباط كل فقرة مع الدرجة الكلية للمحور

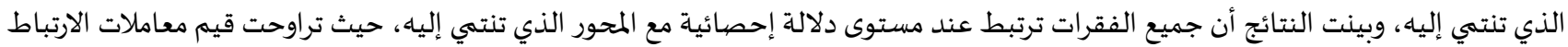
مع المحاور ما بين (0.385 - 0.780)، مما يشير إلى أن جميع الفقرات تتمتع بدرجة مرتفعة من الصددق مع محاورها التي تنتمي إلهها، والجدول الآتي يوضح 
جدول (2): معاملات الارتباط بين درجة كل فقرة مع الدرجة الكلية للمحور الذي تنتهي إليه

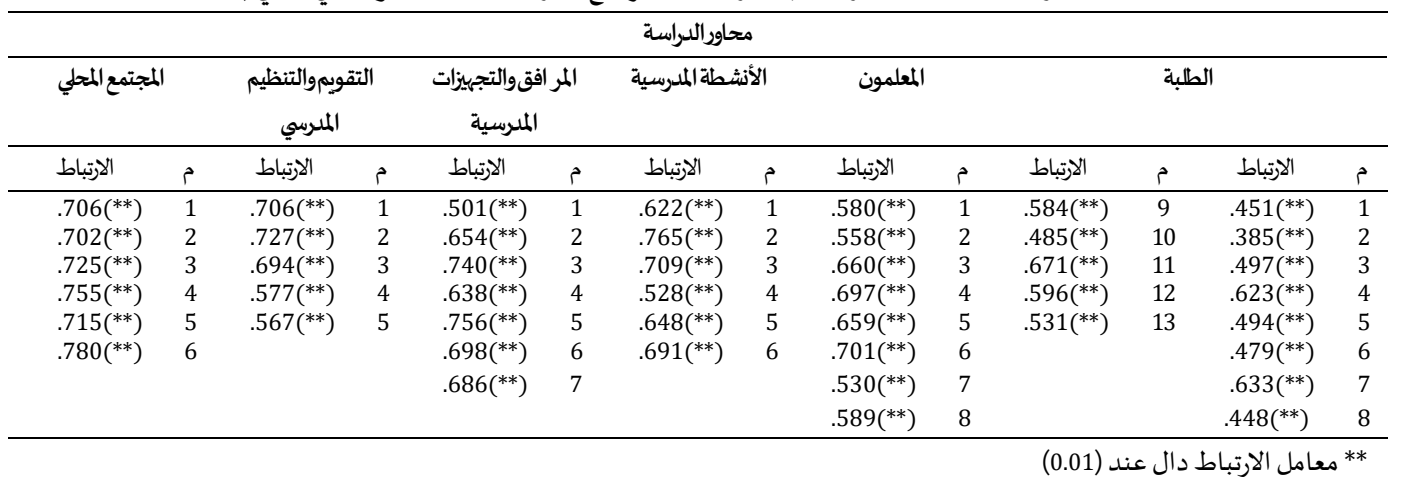

جدول (3): معاملات الارتباط بين درجة كل محورمع الدرجة الكلية لأداة الدراسة

\begin{tabular}{|c|c|c|c|c|c|c|}
\hline الدلدة الدلة & التقويم والتنظيم & المر افق والتجهيزات & المدرسية & المعلمون & الطلبة الطبة & محاور الدراسة \\
\hline $.821\left(^{* *}\right)$ & & & & & 1 & الطلبة \\
\hline $.781\left({ }^{* *}\right)$ & & & & 1 & $.568(* *)$ & المعلمون \\
\hline $\left..760{ }^{* *}\right)$ & & & 1 & $.455(* *)$ & $.555(* *)$ & الأنشطة المدرسية \\
\hline $.715\left(^{* *}\right)$ & & 1 & $.422(* *)$ & $.462(* *)$ & $.498(* *)$ & المرافق والتجهيزات المدرسية \\
\hline $.721\left(^{* *}\right)$ & 1 & $.410\left(^{* *}\right)$ & $.575(* *)$ & $.452(* *)$ & $.499\left(^{* *}\right)$ & التقويم والتنظيم المدرسي \\
\hline $.788\left({ }^{* *}\right)$ & $.553(* *)$ & $.501(* *)$ & $.585(* *)$ & $.600(* *)$ & $.459(* *)$ & المجتمع المحلي \\
\hline
\end{tabular}

يتضح من الجدول (3) أن معاملات الارتباط بين محاور أداة الدراساة مع بعضها ومع الدرجة الكلية جاءت دالة إحصائيًا عند مستوى الدلالة (0.01) حيث تراوحت بين (0.410 - 0.821) وهي قيم ارتباط موجباة وجيدة تشير إلى قوة التماسك الداخلي للاستبانة في كل محاورها.

4.3 ثبات أداة الدراسـة:

للتأكد من ثبات الأداة تم استخدام (معادلة ألفا كرونباخ Cronbach'aAlpha)، والجدول الآتي يوضح النتائج: جدول (4): معامل ألفا كرونباخ للثبات الكلي لأداة الدراسة والمحاور

\begin{tabular}{|c|c|c|}
\hline معامل ألفا كرونباخ & عدد العبارات & محاور أداة الدراسـة \\
\hline 0.787 & 13 & الطلبة \\
\hline 0.771 & 8 & المعلمون \\
\hline 0.736 & 6 & الأنشطة المدرسية \\
\hline 0.794 & 7 & المرافق والتجهيزات المدرسية \\
\hline 0.659 & 5 & التقويم والتنظيم المدرسي \\
\hline 0.825 & 6 & المجتمع المحلي \\
\hline 0.925 & 45 & الدرجة الكلية \\
\hline
\end{tabular}

من الجدول (4) نجد أن معاملات الثبات المقدرة بمعادلة ألفا كرونباخ " ه " لمحاور أداة الدراسة تراوحت بين (0.659- 0.8.25)، بينما بلغت قيمة الثبات حسب معامل ألفا كرونباخ للأدة ككل (0.925) وهي قيم مرتفعة، وتشير إلى أن الأداة تتمتع بدرجة عالية من الثبات الثبات، وبالتالي يمكن الاعتماد على النتائج والوثوق بها.

5.3. المعالجات الإحصيائية المستخدمة:: تم استخدام برنامج الحزم الإحصائية للعلوم الاجتماعية (SPSS) الإصدار (20) في إجراء المعالجة الإحصائية للبيانات، حيث تم استخدام

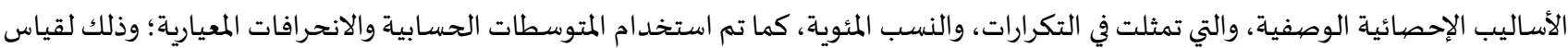

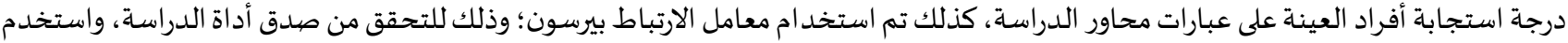

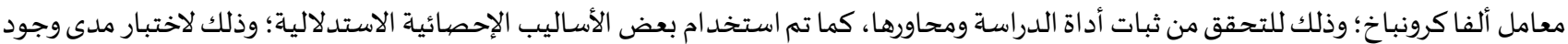
فروق ذات دلالة إحصائية بين استجابات أفرد العينة حول درجة ممارسة القيادة المدرسية لأدوارها في رعاية الطلبة الموهوبين بمحافظة جدة، وتم تقدير

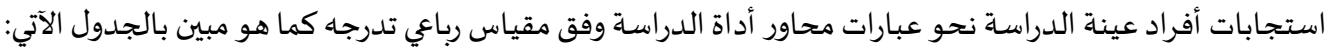


جدول (5): معيار الحكم على استجابات أفراد العينة

\begin{tabular}{|c|c|c|c|c|}
\hline \multirow{2}{*}{ النسبة المئوية } & \multirow{2}{*}{ القيمة } & \multirow{2}{*}{ درجة الممارسة } & \multicolumn{2}{|c|}{ طول الفئة } \\
\hline & & & إلى & من من \\
\hline $100-0.81$ & 4 & كبيرة & 4 & 3.25 \\
\hline $0.80-0.63$ & 3 & متوسطة & 3.24 & 2.50 \\
\hline $0.62-0.44$ & 2 & منخفضة & 2.49 & 1.75 \\
\hline $0.43-0.25$ & 1 & منخفضضة جدًا & 1.74 & 1 \\
\hline
\end{tabular}

4. نتائج الدراسة ومناقشتها

1.4. النتائج المتعلقة بالسؤال الأول: ما درجة ممارسة القيادة المدرسية لأدوارها في رعاية الطلبة الموهوبين بمحافظة جدة من وجهة نظر المعلمين؟ • جدول (6): المتوسطات الحسابية والانحر افات المعيارية والترتيب لمحور الطلبة

\begin{tabular}{|c|c|c|c|c|c|}
\hline 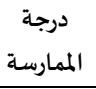 & 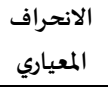 & المتوسط & 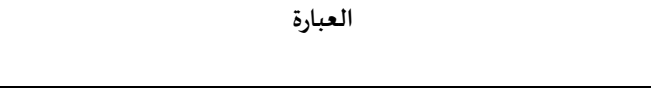 & 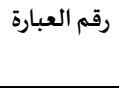 & 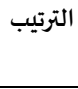 \\
\hline متوسطة & 0.77 & 3.12 & يتبنى قائد المدرسة سياسات تساعد الطلبة على ابتكار الأفكار الإبداعية & 1 & 1 \\
\hline 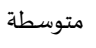 & 0.79 & 2.88 & يشجع الطلبة على المشاركة في البرامج التي تنمي قدرات الطلبة الموهوبين. & 2 & 2 \\
\hline متوسطة & 1.00 & 2.85 & يطبق الأنظمة والقوانين المدرسية على الطلبة بحزم وعدالة & 6 & 3 \\
\hline متوسطة & 0.77 & 2.80 & 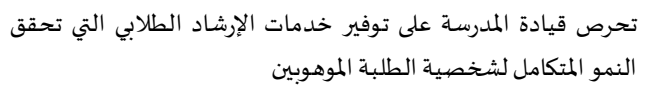 & 10 & 4 \\
\hline متوسطة & 0.90 & 2.76 & يكون علاقات إيجابية مع الطلبة الموهوبين & 4 & 5 \\
\hline متوسطة & 1.02 & 2.76 & يحرص قائد المدرسة على تعزيز القيم والسلوكيات الحميدة لدى الطلاب & 12 & 6 \\
\hline متوسطة & 0.78 & 2.73 & يبرز جهود وابتكارات الطلبة الموهوبين من خلال قنوات مناسبة ومتعددة & 3 & 7 \\
\hline متوسطة & 0.85 & 2.71 & يشجع الطلبة على الالتحاق بالدورات التدريبة لرعاية مواهههم & 9 & 8 \\
\hline 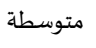 & 0.88 & 2.69 & يقدم الدعم المعنوي للطلبة الموهوبين كلما دعت الحاجة & 7 & 9 \\
\hline 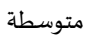 & 0.85 & 2.61 & يشجح الطلاب على إجراء البحوث العلمية والإبداعية التي تظهر موهبتهم & 5 & 10 \\
\hline متوسطة & 0.92 & 2.53 & يوفر قائد المدرسة الرعاية الاجتماعية والنفسية للطلبة الموهوبين & 11 & 11 \\
\hline 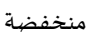 & 0.93 & 2.43 & تنفذ قيادة المدرسة زيارات علمية تسهم في إثراء خبرات ومعارف الطلبة & 13 & 12 \\
\hline 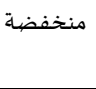 & 0.89 & 2.41 & الطلبة الموهوبيند المدرسة في تقديم بعض الحوافز المادية التي تسهم في تنمية & 8 & 13 \\
\hline متوسطة & 0.87 & 2.71 & المتوسط العام & & \\
\hline
\end{tabular}

يتضيح من الجدول (6) أن المتوسط العام لاستجابات أفراد العينة حول درجة ممارسة القيادة المدرسية لأدوارها في رعاية الطلبة الموهوبين بمحافظة جدة في محور الطلبة بلغ (2.71)، وانحراف معياري قدره (0.87) وبدرجة متوسطة، وقد حصلت المبلت معظم الفقرات على درجة متوسطة، ما عدا فقرتين حصلتا على درجة منخفضية. وتتفق هذه النتيجة مع بعض نتائج دراسـة المطيري وسليمان (2020)، ودراسة البقي (2016) التي أشارت إلى أن دور الإدارة المدرسية في رعاية

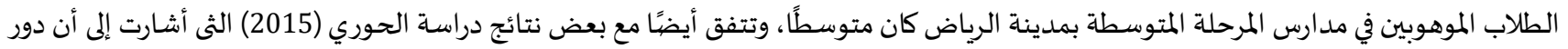

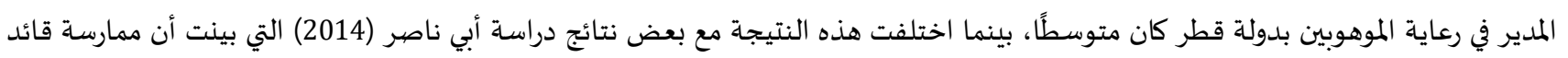

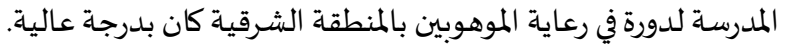
وبترتيب متوسطات استجابات عينة الدراسـة على فقرات محور الطلبة جاءت الفقرة (يتبنى قائد المدرسـة سياسات تساعد الطلبة على ابتكار

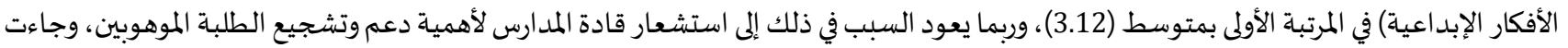

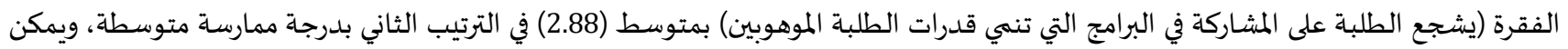

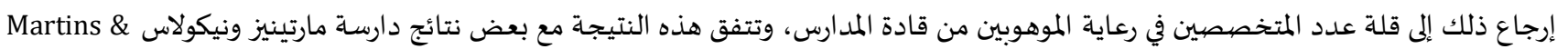
( Nicolas, 2017)

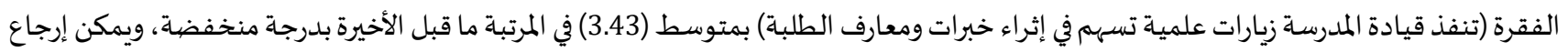


ذلك إلى ضعف الموارد المالية وإلى أهمية موافقات أولياء أمور الطلبة على الزيارات العلمية وأهمية اتخاذ الإجراءات التي تضمن سلامة الطلبة، وتتفق هذه

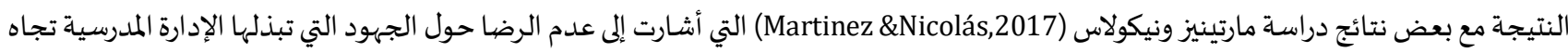
دعم وتعزيز المواهب في تشيلي، ومن ضمن ذلك قلة تنفيذ البرامج الإثرائية, وجاءت الفقرة (يسهم قائد المدرسة في تقديم بعض الحوافز المادية التي تسهم في تنمية الطلبة الموهوبين) في المرتبة الأخيرة بمتوسط فين (2.41) وبدرجة ممارسة منخفضية، ويعود السبب في ذلك إلى عدم وجود مخصصصات مالية كافية تسهم في تنمياة الطلبة الموهوبين، وتختلف هذه النتيجة مع بعض نتائج دراسة أبي ناصر (2014) التي أشارت إلى حصول مديري المدارس في المنطقة الشرقية في مجال تنفيذ الأنشطة المدرسية المتعلقة بالموهوبين على درجة عالية بسبب توفيه توفر الموارد المالية لديهيه. ا محتور الثاني: المعلمون:

جدول (7): المتوسطات الحسابية والانحر افات المعيارية والترتيب لمحور المعلمين

\begin{tabular}{|c|c|c|c|c|c|}
\hline 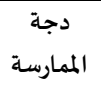 & 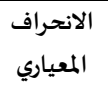 & الحسبط المتوسط & 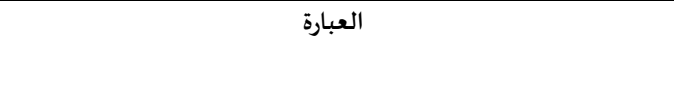 & 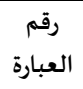 & الترتيب \\
\hline كبيرة & 0.68 & 3.27 & تناسث الطلبة المموسة المعلمين على استخدام طرق التدريس الحديثة التي & 1 & 1 \\
\hline متوسطة & 0.73 & 3.19 & للموهوبين قائد المدرسة للمعلمين أهمية استخدام الوسائط التعليمية المناسبة & 2 & 2 \\
\hline 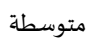 & 0.99 & 2.83 & يراعي الفروق الفردية بين المعلمين من ناحية الإنجاز أو الخبرة المهنية & 3 & 3 \\
\hline متوسطة & 0.85 & 2.69 & يشجع المعلمين على المشاركة في البرامج التي تهتم بتنمية ورعاية الطلبة & 6 & 4 \\
\hline 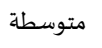 & 0.97 & 2.68 & يقدم المساعدة والنصح للمعلمين حديثي الانضمام بالمدرسة & 7 & 5 \\
\hline متوسطة & 0.97 & 2.61 & لدورهم التعليمي والتربوي في تخفيف الأعباء الملمقاة على المعلمين حتى يتفرغوا & 5 & 6 \\
\hline 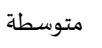 & 0.97 & 2.60 & يتعامل قائد المدرسة بموضوعية وعدالة مع جميع المعلمين & 4 & 7 \\
\hline 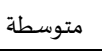 & 0.86 & 2.52 & يحث المعلمين على حضور اللقاءات العلمية التي تنمي الإبداع & 8 & 8 \\
\hline 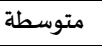 & 0.88 & 2.80 & المتوسط العام & & \\
\hline
\end{tabular}

يتضح من الجدول (7) أن المتوسط العام لاستجابات أفراد العينة حول درجة ممارسة القيادة المدرسية لأدوارها في رعاية الطلبة الموهوبين

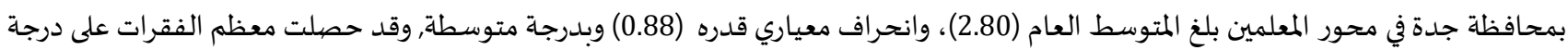
متوسطة، ما عدا فقرة واحدة حصلت على درجة كبيرة، وربما يعود السبب في ذلك إلى عدم قدرة قادة المدارس على تخفيف الأعباء الملقاة على المعلمين حتى يتفرغوا لدورهم التعليمي والتربوي للموهوبين بشكل مناسب، بسبب نقص أعداد معلمي الموهوبين والكوادر الإدارية المساعدة. وتتفق هذه النتيجة مع بعض نتائج دراسة سعادة (2020) التي أظهرت نتائجها أن درجة اهتمام الإدارة المدرسية بالطلبة الموهوبين في المدارس الحكومية بعدئ بعمان

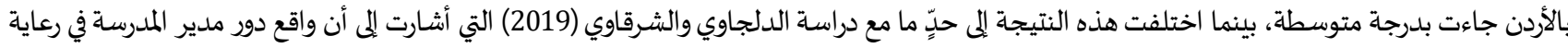

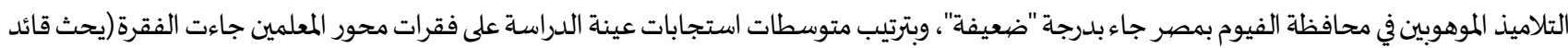
المدرسة المعلمين على استخدام طرق التدريس الحديثة التي تناسب الطلبة الموهوبين) في المرتبة الأولى بمتوسط (3.27) كأبرز أدوار قادة المدارس في رعاية الطلبة

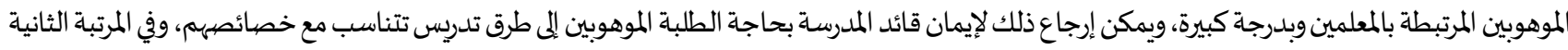

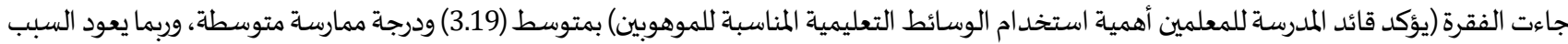
في ذلك إلى توافر الوسائط التعليمية في مدارس الموهوبين وإدراك المعلمين لأهميتها في العملية التعليمية، وفي المرتبة ما قبل الأخيرة جاءت الفقرة (يتعامل قائد المدرسة بموضوعية وعدالة مع جميع المعلمين) بمتوسط (2.60) ودرجة ممارسة متوسطة, ويمكن إرجاع ذلك إلى افتقاد بعض قادة المدارس لمهارات التعامل مع المعلمين، وفي

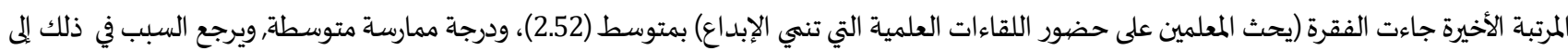
ارتفاع أنصبة المعلمين.

م المحور الثالث: الأنشطة المدرسية:

جدول (8): المتوسطات الحسابية والانحر افات المعيارية والترتيب لمحور الأنشطة المدرسية

\begin{tabular}{|c|c|c|c|c|c|}
\hline الممارسة درجة & المعياري & الحسابي & 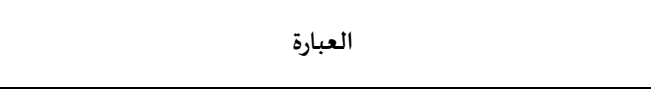 & 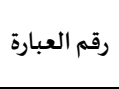 & 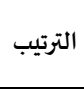 \\
\hline 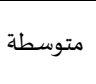 & 0.74 & 2.99 & يوفر قائد المدرسة الممافق المناسبة لممارسة الأنشطة والمسابقات & 1 & 1 \\
\hline متوسطة & 0.82 & 2.88 & يحيول الطلبة الموهوبين على أن تتوافق الأنشطة المدرسية مع اهتمامات & 2 & 2 \\
\hline 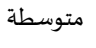 & 0.89 & 2.67 & يشرف قائد المدرسة على الطلبة أثناء ممارسة الأنشطة الممدرسية & 4 & 3 \\
\hline
\end{tabular}




\begin{tabular}{|c|c|c|c|c|c|}
\hline متوسطة & 0.89 & 2.60 & يمهارات الطلبة الموهوبينة في إقامة بعض المعارض والمسابقات العلمية المعززة & 3 & 4 \\
\hline متوسطة & 1.09 & 2.60 & يتواصل قائد المدرسة مع الجهات والأفراد ذات العلاقة لدعم الأنشطة & 6 & 5 \\
\hline منخفضضة & 0.91 & 2.31 & يخصص قائد المدرسة ميزانية للأنشطة والبرامج الخاصة برعاية & 5 & 6 \\
\hline متوسطة & 0.89 & 2.67 & المتوسط العام & & \\
\hline
\end{tabular}

يتضح من الجدول (8) أن المتوسط العام لاستجابات أفراد العينة حول درجة ممارسة القيادة المدرسية لأدوارها في رعاية الطلبة الموهوبين بمحافظة جدة في في

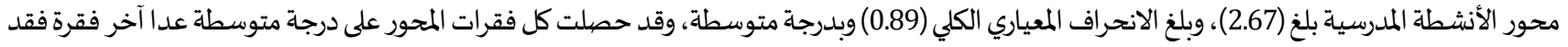

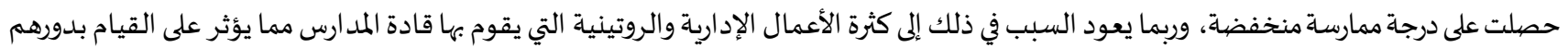

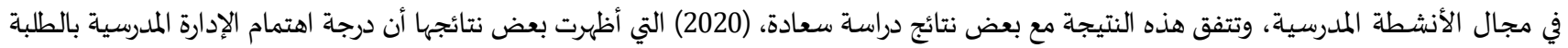

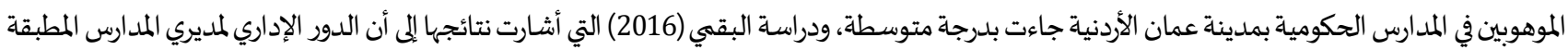

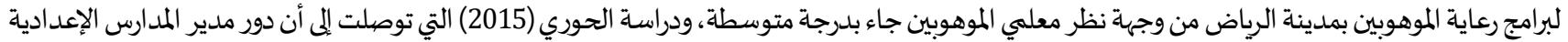

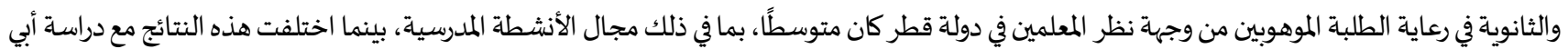

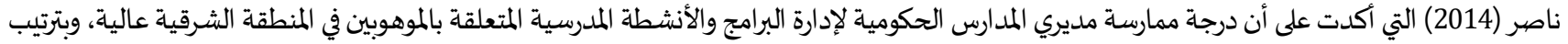

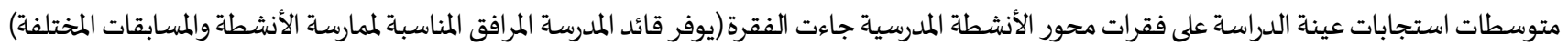

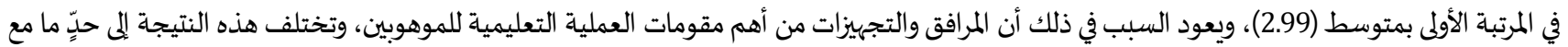

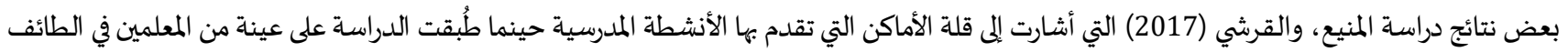

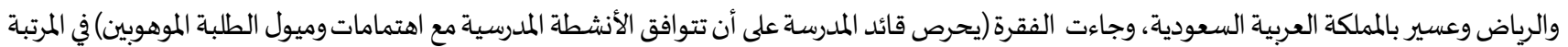

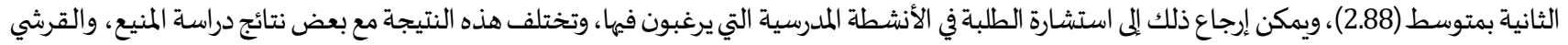

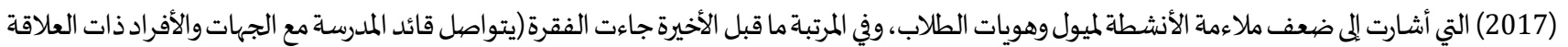
لدعم الأنشطة الخاصة بالموهوبين) بمتوسط (2017) (2.60)، وانحراف معياري (1.09)، وتختلف هذه النتيجة مع بعض نتائج دراسة أبي ناصر (2016) التي جاءت نتائجها

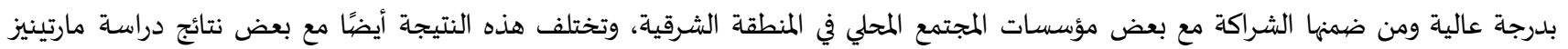

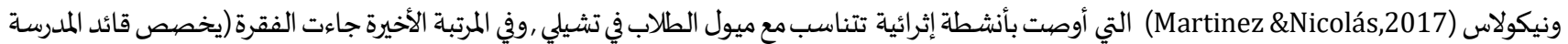

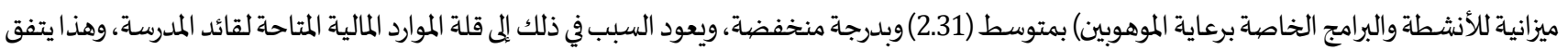
مع دراسة المنيع، والقرشي (2017) التي أشارت بعض نتائجها المى ضعف الإمكانات المالية والاعتمادات اللازمة لممارسة الأنشطة المدرسية للموهوبين في تعليم الرياض الماضية

جدول (9): المتوسطات الحسابية والانحر افات المعيارية والترتيب لمحور المر افق والتجهيزات المدرسية

\begin{tabular}{|c|c|c|c|c|c|}
\hline درجة الممارسة & الانحراف & الحستطابي & 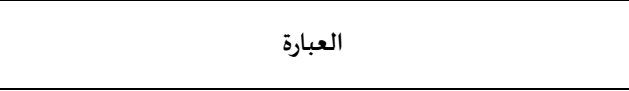 & 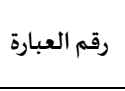 & الترتيب \\
\hline متوسطة & 0.80 & 3.18 & يحرص قائد المدرسة على أن تتوافر بالمبنى المدرسي الشروط الصحية & 1 & 1 \\
\hline متوسطة & 0.78 & 2.79 & للطوفر قائد المدرسة المتطلبات التعليمية والتقنية في القاعات الدراسية & 2 & 2 \\
\hline متوسطة & 0.84 & 2.55 & 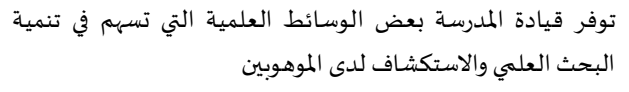 & 3 & 3 \\
\hline متوسطة & 0.82 & 2.51 & تالعوافر بمختبر المدرسة الأدوات والأجهزة اللازمة لإجراء التجارب & 4 & 4 \\
\hline منخفضية & 0.93 & 2.27 & للطلبة الموهوبين ائد المدرسة بالمكتبة المدرسية المصادر والمراجع العلمية الملائمة & 6 & 5 \\
\hline منخفضية & 0.96 & 2.37 & الموهوبين المقاييس والاختبارات الملائمة لقياس النمو العلمي للطلبة & 5 & 6 \\
\hline منخفضية جدًا & 0.85 & 1.74 & توفر قيادة المدرسة وسائل النقل للطلبة لمن يحتاجها & 7 & 7 \\
\hline منخفضية & 0.85 & 2.48 & المتوسط العام & & \\
\hline
\end{tabular}


يتضح من الجدول (9) أن المتوسط العام لاستجابات أفراد العينة حول درجة ممارسة القيادة المدرسية لأدوارها في رعاية الطلبة الموهوبين بمحافظة جدة في

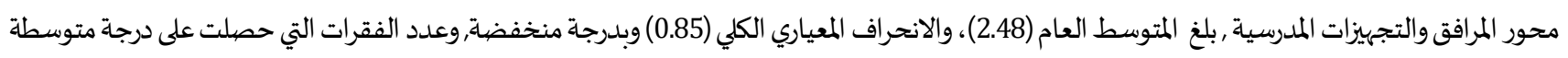
(4) فقرات، وعلى درجة منخفضية فقرتين، وعلى درجة منخفضة جدًا فقرة واحدة، وربما يعود السبب في ذلك إلى قلة المخصصيات المالية والموارد التي بحوزة قادة

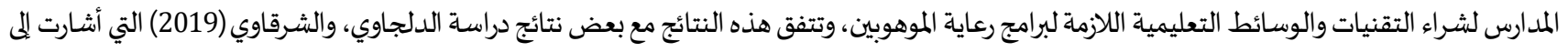
أن دور مدير المدرسة في رعاية التلاميذ الموهوبين في محافظة الفيوم بمصر جاء بدرجة "ضعيفة"، وتختلف هذه النتيجة مع بعض نتائج دراسة الحوري (2015) التي

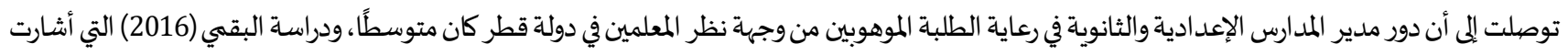

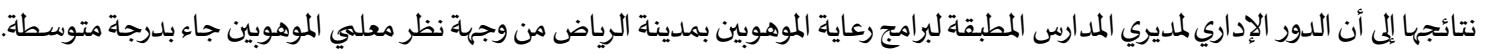

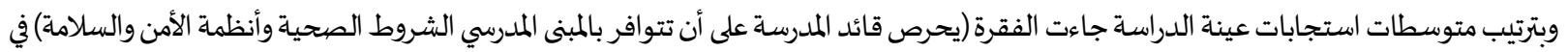

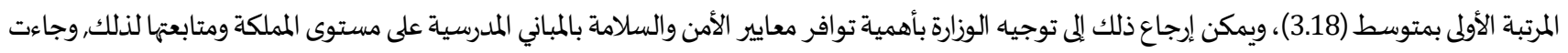

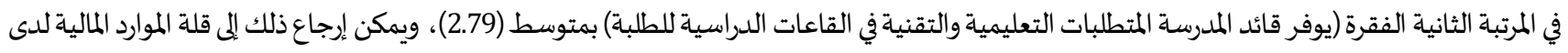

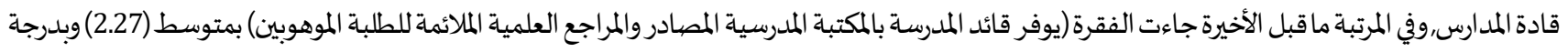
منخفضاة، وهذه النتيجة تختلف مع بعض نتائج دراسة عناني (2012) بمنطقة العين التعليمية بالأمارات حيث أشارت إلى أن دور مدير المدرسة في توفير المراجع

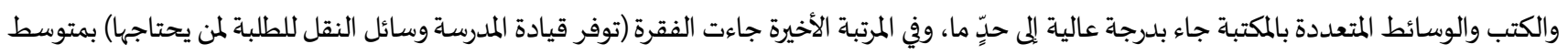
(1.74) وبدرجة منخفضة،، ويعود السبب في ذلك لعدم توفر المصادر المالية الكافية لدى قائد المدرسة. • • ب المحور الخامس: التقويم والتنظيم المدرسي:

\begin{tabular}{|c|c|c|c|c|c|}
\hline الم الممارسة & 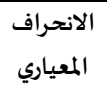 & الحستبط & 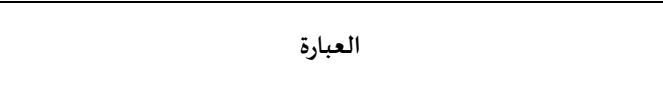 & 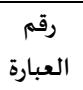 & الترتيب \\
\hline متوسطة & 0.90 & 2.81 & يشيَم قائد المدرسة الخطط التعليمية والأنشطة المدرسية للطلبة الموهوبين & 1 & 1 \\
\hline متوسطة & 0.88 & 2.67 & يشارك قائد المدرسة المعلمين في وضع الخطط الللازمة لرعاية الطلبة & 3 & 2 \\
\hline متوسطة & 0.91 & 2.73 & الموهوبين قيادة المدرسة الأساليب العلمية والتربوية الحديثة في رعاية الطلبة & 2 & 3 \\
\hline متوسطة & 1.02 & 2.55 & يحرص قائد المدرسة على استقطاب المعلمين الأكفاء للعمل بمدارس & 5 & 4 \\
\hline متوسطة & 0.93 & 2.59 & يوفر قائد المدرسة المناخ التنظيهي الملائم لرعاية الطلبة الموهوبين & 4 & 5 \\
\hline متوسطة & 0.93 & 2.67 & المتوسط العام & & \\
\hline
\end{tabular}

يتضح من الجدول (10) أن المتوسط العام لاستجابات أفراد العينة حول درجة ممارسة القيادة المدرسية لأدوارها في رعاية الطلبة الموهوبين بمحافظة جدة في محور التقويم والتنظيم المدرسي بلغ (2.76)، وبلغ الانحراف المعياري الكلي (0.93) وبدرجة متوسطة, وقد حصلت كل فقرات المحور على درجة متوسطة، وتتفق

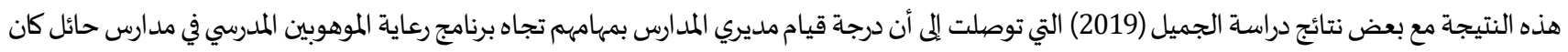
متوسطًا, بينما اختلفت هذه النتيجة مع بعض نتائج دراسة أبي ناصر (2014) التي أشارت إلى أن درجة ممارسة مديري المدارس الحكيل المكومية لإدارة البرامج والأنشطة المدرسية المتعلقة بالموهوبين في المنطقة الشرقية عالية. وبترتيب متوسطات استجابات عينة الدراسة على فقرات محور التقويم والتنظيم المدرسي جاءت الفقرة (يقيَم قائد المدرسة الخطط التعليمية والأنشطة

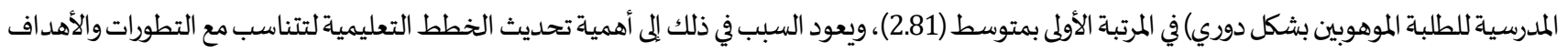

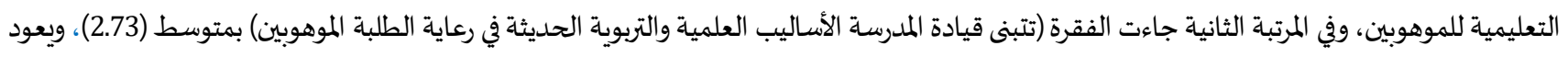

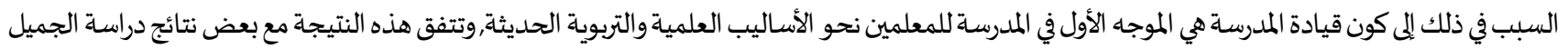

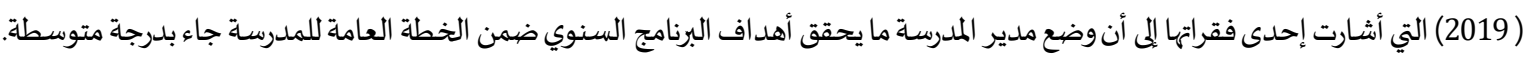

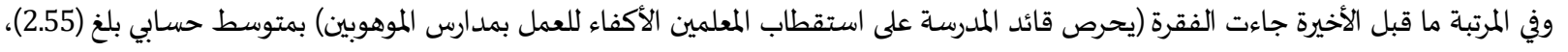
وتختلف هذه النتيجة مع بعض نتائج دراسة المطيري وسليمان (2020) التي أشارت نتائجها المى أهمية دور الإدارة المدرسية في رعاية الطلاب الموهوبين في مدارس الماتئل المرحلة

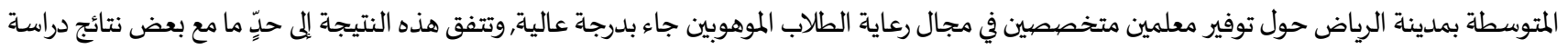

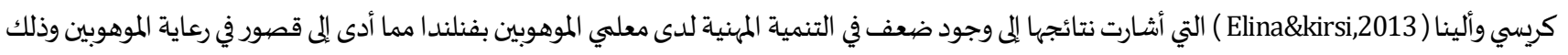
بسبب عدم وجود المعلمين الأكفاء, وجاءت في المرتبة الأخيرة الفقرة (يوفر قائد المدرسة المناخ التنظيمي الملائم لرعاية الطلبة الموهوبين) بمتوسط (لمائين (2.59)، وربما يعود

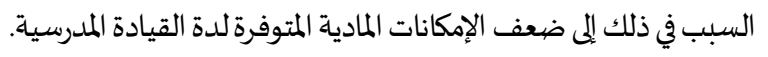


•

\begin{tabular}{|c|c|c|c|c|c|}
\hline 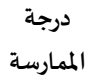 & 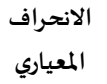 & 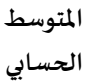 & 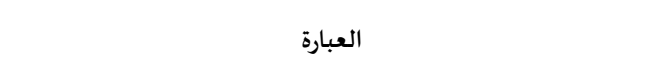 & 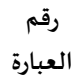 & 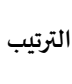 \\
\hline متوسطة & 0.90 & 2.92 & يعزز قائد المدرسة دور الأسرة في رعاية أبنائهم الموهوبين & 1 & 1 \\
\hline متوسطة & 0.89 & 2.91 & لقدرات الطلبة الموهوبين ألمدر الموهوبين على المشاركة في البرامج المجتمعية المعززة & 2 & 2 \\
\hline متوسطة & 0.88 & 2.69 & يوفر قائد المدرسة قنوات متعددة للتواصل مع أسر الطلبة الموهوبين & 3 & 3 \\
\hline متوسطة & 0.98 & 2.55 & رعاية الموهبة والإبداعد المدرسة لقاءات دورية مع أولياء الأمور؛ لتحقيق سُبل التكامل في & 4 & 4 \\
\hline متوسطة & 0.93 & 2.67 & اكتشاف ورعاية الطلبة الموهوبين الوعي بين المدرسة أفراد المجتمع المحيط بأهمية & 5 & 5 \\
\hline 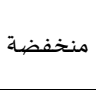 & 1.04 & 2.36 & يقيم قائد المدرسة شراكات مع بعض الشركات المحلية لدعم ورعاية الطلبة & 6 & 6 \\
\hline متوسطة & 0.94 & 2.68 & المتوسط العام & & \\
\hline
\end{tabular}

يتضح من الجدول (11) أن المتوسط العام لاستجابات أفراد العينة حول درجة ممارسة القيادة المدرسية لأدوارها في رعاية الطلبة الموهوبين بمحافظة جدة

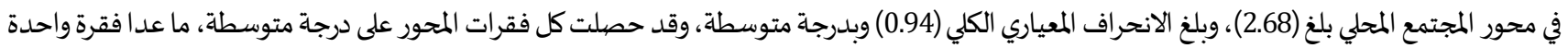
حصلت على درجة منخفضاة، ويعود السبب في ذلك إلى ضعف تعاون بعض أفراد المجتمع المحلي ومؤسساته مع مدارس الموهوبين، وتختلف هذه النتيجة مع بعض

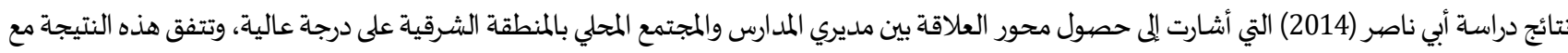
بعض نتائج دراسة الحوري (2015) التي أجريت في قطر وأشارت إلى حصول دور مدير المدرسة في العلاقة بالمجتمع المحلي على درجة متوسطة. وبترتيب متوسطات استجابات عينة الدراسة على فقرات محور المجتمع المحلي جاءت الفقرة (يعزز قائد المدرسة دور الأسرة في رعاية أبنائهم الموهوبين) في

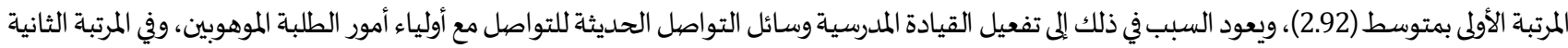
جاءت الفقرة (يحث قائد المدرسة أسر الموهوبين على المشاركة في البرامج المجتمعية المعززة لقدرات الطلبة الموهوبين) بمتوسط (2.91)، وفي المرتبة ما قبل الأخيرة

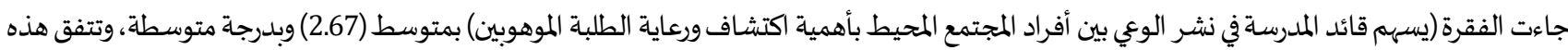

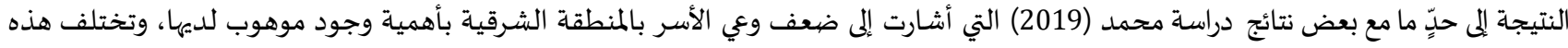
النتيجة مع بعض نتائج دراسة مارتينيز ونيكولاس (Martinez \& Nicolas,2017) التي أكدت على أهمية الكشف عن عن الطلاب الموهوبين ورعايتهم من خلال استراتيجيات خاصة ومنها تعاون أفراد المجتمع معهم في الكشف عن الطلبة الموهوبين، وفي المرتبة الأخيرة جاءت الفقرة ( يقيم قائد المدرسة شراكات مع بعض الشركات المحلية لدعم ورعاية الطلبة الموهوبين) بمتوسط (2.36) وبدرجة منخفضة، ويعود السبب في ذلك لضيعف مرونة الأنظمة التعليمية فيما يتعلق بإقامة الشراكات

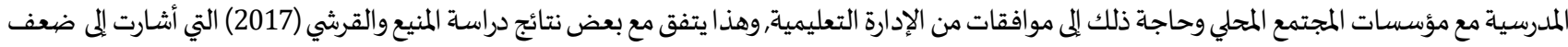
مستوى التنسيق بين المؤسسات الوطنية والمدرسة في مجال دعم الأنشطة لرعاية الموهوبين.

2.4. النتائج المتعلقة بالسؤال الثاني: هل توجد فروق ذات دلالة إحصيائية بين استجابات أفراد العينة حول درجة ممارسة القيادة المدرسية لأداورها

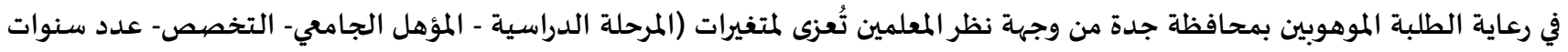

الخدمة - الدورات التأهيلية في رعاية الموهوبين )؟ جدول (12): اختبار (ت) للفروق وفقًا لمتغير المؤهل الدراسي

\begin{tabular}{|c|c|c|c|c|c|c|c|}
\hline الدلالة الدالة & اختبار"ت" & الحرية & الالمعراف & المتوسط & العينة & المؤهل الدراسي & المحاور \\
\hline 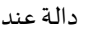 & \multirow{2}{*}{$5.737^{*}$} & \multirow{2}{*}{223} & 5.2 & 33.9 & 159 & بكالوريوس & \multirow{2}{*}{ الطلبة } \\
\hline$(0.01)$ & & & 6.5 & 38.6 & 66 & الدراسات العليا & \\
\hline دالة عند & \multirow{2}{*}{$5.491^{*}$} & \multirow{2}{*}{223} & 4.0 & 21.4 & 159 & بكالوريوس & \multirow{2}{*}{ المعلمين } \\
\hline$(0.01)$ & & & 4.3 & 24.7 & 66 & الدراسات العليا & \\
\hline 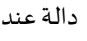 & \multirow{2}{*}{$4.862^{*}$} & \multirow{2}{*}{223} & 3.3 & 15.3 & 159 & بكالوريوس & \multirow{2}{*}{ الأنشطة المدرسية } \\
\hline$(0.01)$ & & & 3.5 & 17.7 & 66 & الدراسات العليا & \\
\hline 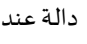 & \multirow{2}{*}{$4.519^{*}$} & \multirow{2}{*}{223} & 3.6 & 17.4 & 159 & بكالوريوس & \multirow{2}{*}{ المرافق والتجهيزات المدرسية } \\
\hline$(0.01)$ & & & 4.3 & 19.9 & 66 & الدراسات العليا & \\
\hline 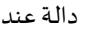 & \multirow{2}{*}{$6.054^{*}$} & \multirow{2}{*}{223} & 2.7 & 12.6 & 159 & بكالوريوس & \multirow{2}{*}{ التقويم والتنظيم المدرسي } \\
\hline$(0.01)$ & & & 3.0 & 15.1 & 66 & الدراسات العليا & \\
\hline
\end{tabular}




\begin{tabular}{|c|c|c|c|c|c|c|c|}
\hline الدلالة & اختـار"ت" & الحربة & الانحراف & المتوسط & العينة & المؤهل الدراسي & المحاور \\
\hline دالة عند & $5.862^{*}$ & 223 & $\begin{array}{l}3.7 \\
4.1\end{array}$ & $\begin{array}{l}15.1 \\
18.4\end{array}$ & $\begin{array}{c}159 \\
66\end{array}$ & بكالوريوس & المجتمع المحلي \\
\hline
\end{tabular}

* دال إحصائيًا عند مستوى الدلالة (0.01)

يتضح من الجدول (12) أن قيم (ت) للفروق بين استجابات أفراد عينة الدراسة حول درجة ممارسة القيادة المدرسية لأدوارها في رعاية الطلبة الموهوبين

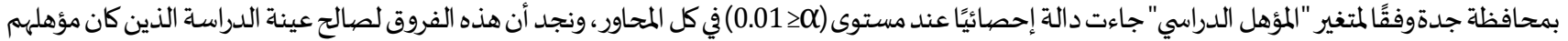

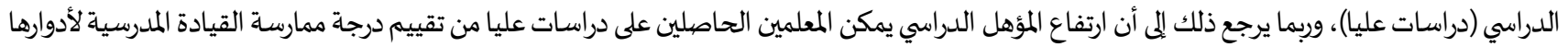

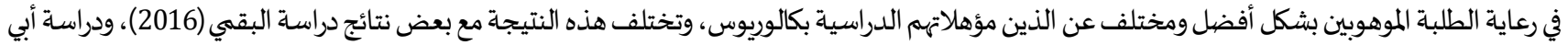
ناصر (2016) اللتين توصلتا إلى عدموجود فروق دالة احصائيًا في استجابات أفراد العيناة تبعًا لمؤهلاتهم الدراسية.

جدول (13): اختبار (ت) للفروق وفقًا لمتغيرنوع التخصص

\begin{tabular}{|c|c|c|c|c|c|c|c|}
\hline مستوى الدلالة & اختبار"ت" & درجة الحرية & الانحراف المعياري & المتوسط & العينة & التخصص & المحاور \\
\hline .924 & \multirow{2}{*}{-.096} & \multirow{2}{*}{223} & 5.7 & 35.3 & 117 & أدبي & \multirow{2}{*}{ الطلبة } \\
\hline غير دالة & & & 6.4 & 35.3 & 108 & علمي & \\
\hline .721 & \multirow{2}{*}{.358} & \multirow{2}{*}{223} & 3.9 & 22.5 & 117 & أدبي & \multirow{2}{*}{ المعلمون } \\
\hline غير دالة & & & 4.8 & 22.3 & 108 & علي & \\
\hline .189 & \multirow{2}{*}{-1.317} & \multirow{2}{*}{223} & 3.5 & 15.7 & 117 & أدبي & \multirow{2}{*}{ الأنشطة المدرسية } \\
\hline غير دالة & & & 3.5 & 16.4 & 108 & علي & \\
\hline 666 & \multirow{2}{*}{.433} & \multirow{2}{*}{223} & 4.1 & 18.2 & 117 & أدبي & \multirow{2}{*}{ المرافق والتجهييزات } \\
\hline غير دالة & & & 3.9 & 18.0 & 108 & علمي & \\
\hline .204 & \multirow{2}{*}{-1.273} & \multirow{2}{*}{223} & 3.0 & 13.1 & 117 & أدبي & \multirow{2}{*}{ التقويم والتنظيم المدرسي } \\
\hline غير دالة & & & 3.0 & 13.6 & 108 & علمي عي & \\
\hline .582 & \multirow{2}{*}{-.551} & \multirow{2}{*}{223} & 4.1 & 15.9 & 117 & أدبي & \multirow{2}{*}{ المجتمع المحلي } \\
\hline غير دالة & & & 4.1 & 16.3 & 108 & علمي & \\
\hline
\end{tabular}

يتضح من الجدول (13) أن قيم (ت) للفروق بين استجابات أفراد عينة الدراسة حول درجة ممارسة القيادة المدرسية لأدوارها في رعاية الطلبة الموهوبين

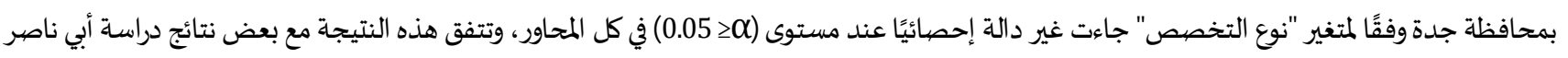
(2016) التي أشارت إلى عدم وجود فروق تبعًا للتخصص.

متغير الدورات التدريبية في رعاية الموهوبين:

جدول (14): اختبار(ت) للفروق وفقًا لمتغير الدورات التدريبية في رعاية الموهوبين

\begin{tabular}{|c|c|c|c|c|c|c|c|}
\hline الدلالة & "اختبار & الحرجة & الانحراف & المتوسط & العينة & عدد الدورات التدريبية & المحاور \\
\hline دالة عند & \multirow{2}{*}{$4.515^{*}$} & \multirow{2}{*}{223} & 4.8 & 33.9 & 138 & أقل من 3 دورات & \multirow{2}{*}{ الطلبة. } \\
\hline$(0.01)$ & & & 7.1 & 37.5 & 87 & أكثر من 3 دورات & \\
\hline دالة عند & \multirow{2}{*}{$4.052^{*}$} & \multirow{2}{*}{223} & 4.1 & 21.5 & 138 & أقل من 3 دورات & \multirow{2}{*}{ المعلمين } \\
\hline$(0.01)$ & & & 4.4 & 23.8 & 87 & أكثر من 3 دورات & \\
\hline دالة عند & \multirow{2}{*}{$3.321^{*}$} & \multirow{2}{*}{223} & 3.5 & 15.4 & 138 & أقل من 3 دورات & \multirow{2}{*}{ الأنشطة المدرسية. } \\
\hline$(0.01)$ & & & 3.4 & 17.0 & 87 & أكثر من 3 دورات & \\
\hline دالة عند & \multirow{2}{*}{$5.660^{*}$} & \multirow{2}{*}{223} & 3.5 & 17.0 & 138 & أقل من 3 دورات & \multirow{2}{*}{ المرافق والتجهييزات } \\
\hline$(0.01)$ & & & 4.1 & 19.9 & 87 & أكثر من 3 دورات & \\
\hline دالة عند & \multirow{2}{*}{$3.651^{*}$} & \multirow{2}{*}{223} & 2.3 & 12.8 & 138 & أقل من 3 دورات & \multirow{2}{*}{ التقويم والتنظيم المدرسي. } \\
\hline$(0.01)$ & & & 3.7 & 14.2 & 87 & أكثر من 3 دورات & \\
\hline دالة عند & \multirow{2}{*}{$4.303^{*}$} & \multirow{2}{*}{223} & 3.9 & 15.2 & 138 & أقل من 3 دورات & \multirow{2}{*}{ المجتمع المحلي. } \\
\hline$(0.01)$ & & & 4.0 & 17.5 & 87 & أكثر من 3 دورات & \\
\hline
\end{tabular}

* دال إحصائيًا عند مستوى الدلالة (0.01)

يتضح من الجدول (14) أن قيم(ت) للفروق بين استجابات أفراد عينة الدراسة حول درجة ممارسة القيادة المدرسية لأدوارها في رعاية الطلبة الموهوبين بمحافظة

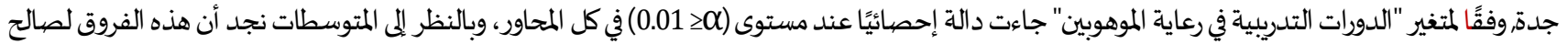
عينة الدراسة الذين تلقوا اكثر من 3 دورات تدربية في رعاية الموهوبين، ويمكن إرجاع ذلك المى رفح الدورات التدريبية التي تلقاها أفراد العينة للمستوى المعرفي لدى المعلمينين 
حول رعاية قادة المدارس للطلبة الموهوبين وإدراكهم للجهود التي يقومون بها تجاه الطلبة، وتختلف هذه النتيجة مع بعض نتائج دراسة البقي (2016) ودراسة أبي ناصر

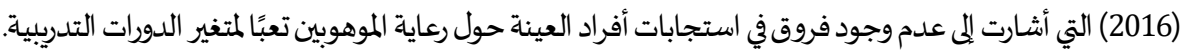

المرحلة الدراسية:

جدول (15): تحليل التباين (ANOVA) للفروق وفقًا لمتغير المرحلة الدراسية

\begin{tabular}{|c|c|c|c|c|c|c|}
\hline الدلالة & قيمة "ف" & متوسط المربعات & درجات الحربة & مجموع المربعات & مصدر التباين & المحاور \\
\hline \multirow{2}{*}{ غير دالة } & \multirow{2}{*}{1.815} & 64.751 & 2 & 129.503 & بين المجموعات & \multirow{2}{*}{ الطلبة } \\
\hline & & 34.447 & 222 & 7647.137 & داخل المجموعات & \\
\hline \multirow{2}{*}{ غير دالة } & \multirow{2}{*}{1.972} & 37.496 & 2 & 74.993 & بين المجموعات & \multirow{2}{*}{ المعلمون } \\
\hline & & 19.011 & 222 & 4220.367 & داخل المجموعات & \\
\hline \multirow{2}{*}{ (0.01) } & \multirow{2}{*}{$7.504^{*}$} & 87.850 & 2 & 175.700 & بين المجموعات & \multirow{2}{*}{ الأنشطة المدرسية } \\
\hline & & 11.707 & 222 & 2598.940 & داخل المجموعات & \\
\hline \multirow{2}{*}{ (0.01) } & \multirow{2}{*}{$5.596^{*}$} & 85.523 & 2 & 171.045 & بين المجموعات & \multirow{2}{*}{ المرافق والتجهيزات } \\
\hline & & 15.282 & 222 & 3392.715 & داخل المجموعات & \\
\hline \multirow{2}{*}{ دالة عند } & \multirow{2}{*}{$24.496^{*}$} & 181.962 & 2 & 363.923 & بين المجمموعات & \multirow{2}{*}{ التقويم والتنظيم } \\
\hline & & 7.428 & 222 & 1649.037 & داخل المجموعات & \\
\hline \multirow{2}{*}{ دالة عند } & \multirow{2}{*}{$19.363^{*}$} & 278.579 & 2 & 557.159 & بين المجموعات & \multirow{2}{*}{ المجتمع المحلي } \\
\hline & & 14.387 & 222 & 3193.881 & داخل المجموعات & \\
\hline
\end{tabular}

يتضح من الجدول (15) أن قيم(ف) للفروق بين استجابات أفراد عينة الدراسة حول درجة ممارسة القيادة المدرسية لأدوارها في رعاية الطلبة الموهوبين بمحافظة في محور (الطلبة- المعلمين) غير دالة إحصائيًا بينما نجد أن هنالك فروقًافي استجابات عينة الدراسة حول درجة ممارسة القيادة المدرسية لأدوارها في رعاية الطلبة الموهوبين بمحافظة جدة في محور (الأنشطة المدرسية- المرافق والتجهيزات المدرسية- التقويموالتنظيم المدرسي-المجتمع المحلي) وفقًا لمتغير المرحلة الدراسية، ولمعرفة اتجاه الفروق تم إجراء اختبار شيفياء والنتائج في الجدول (16) الآتي توضح ذلكّه:

جدول (16): اختبارشيفيه لدلالة الفروق تبعًا لمتغير المرحلة الدراسية

\begin{tabular}{|c|c|c|c|c|}
\hline مستوى الدلالة & الفرق يين المتوسطين & & & المحور \\
\hline 0.001 & $-2.10087(*)$ & متوسطة & \multirow[t]{2}{*}{ إبتدائي } & \multirow{6}{*}{ الأنشطة المدرسية } \\
\hline 0.003 & $-1.66828\left(^{*}\right)$ & ثانوي & & \\
\hline 0.001 & $2.10087\left(^{*}\right)$ & إبتدائي & \multirow[t]{2}{*}{ متوسطة } & \\
\hline 0.431 & .43259 & 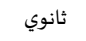 & & \\
\hline 0.003 & $1.66828\left(^{*}\right)$ & إبتدائي & \multirow[t]{2}{*}{ 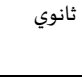 } & \\
\hline 0.431 & -.43259 & متوسطة & & \\
\hline 0.001 & $-2.13043\left(^{*}\right)$ & متوسطة & \multirow{2}{*}{ إبتدائي } & \multirow{6}{*}{ المرافق والتجهييزات المدرسية } \\
\hline 0.020 & $-1.50081\left(^{*}\right)$ & 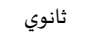 & & \\
\hline 0.001 & $2.13043\left(^{*}\right)$ & إبتدائي & \multirow{2}{*}{ متوسطة } & \\
\hline 0.316 & .62963 & ثانوي & & \\
\hline 0.020 & $1.50081\left(^{*}\right)$ & إبتدائي & \multirow{2}{*}{ ثانوي } & \\
\hline 0.316 & -.62963 & متوسطة & & \\
\hline 0.001 & $-2.72522(*)$ & متوسطة & \multirow{2}{*}{ إبتدائي } & \multirow{6}{*}{ التقويم والتنظيم المدرسي } \\
\hline 0.001 & $-2.78744(*)$ & ثانوي & & \\
\hline 0.001 & $2.72522\left(^{*}\right)$ & إبتدائي & \multirow{2}{*}{ متوسطة } & \\
\hline 0.887 & -.06222 & 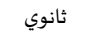 & & \\
\hline 0.001 & $2.78744\left(^{*}\right)$ & إبتدائي & \multirow{2}{*}{ 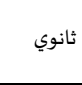 } & \\
\hline 0.887 & .06222 & متوسطة & & \\
\hline 0.001 & $-3.90261(*)$ & متوسطة & \multirow{2}{*}{ إبتدائي } & \multirow{6}{*}{ المجتمع المحلي } \\
\hline 0.011 & $-1.59742\left(^{*}\right)$ & ثانوي & & \\
\hline 0.001 & $3.90261\left(^{*}\right)$ & إبتدائي & \multirow{2}{*}{ متوسطة } & \\
\hline 0.001 & $2.30519\left(^{*}\right)$ & 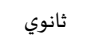 & & \\
\hline 0.011 & $1.59742\left(^{*}\right)$ & إبتدائي & \multirow[t]{2}{*}{ ثانوي } & \\
\hline 0.001 & $-2.30519\left(^{*}\right)$ & متوسطة & & \\
\hline
\end{tabular}

* مال إحصائيًا عند مستوى الدلالة (0.01) 
يتضح من الجدول (16) أن المقارنات بين متوسطات استجابات عينة الدراسة حول درجة ممارسة القيادة المدرسية لأدوارها في رعاية الطلبة الموهوبين بمحافظة

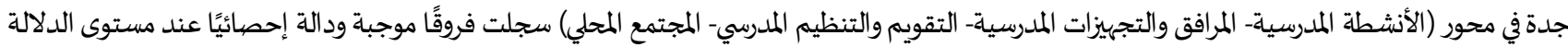
(0.01) بين معلمي المرحلة الابتدائية ومعلمي المرحلة المتوسطة لصالح معلمي المرحلة المتوسطة، كما سجلت فروقًا موجبة ودالة إحصائيًا بين معلمي المرحلة الثانوية ومعلمي

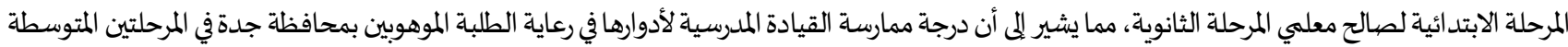
والثانوية والمتعلقة بمحور (الأنشطة المدرسية- المرافق والتجهيزات المدرسية- التقويمووالتنظيم المدرسي-المجتمع المحلي) أفضل من نظرائهم بالمرحلة الابتدائية.

\section{• متغير عدد سنوات الخدمة:}

بما أن هنالك تباين كبير في حجم العيانات الثلاث لفئات عدد سنوات الخدمة لعدئ لعينة الدراسة (أقل من 5 سنوات (18)-من 5 سنوات إلى أقل من 10 سنوات(90) -من 10سنوات فأكثر (117))، فقد تم اختبار تجانس البيانات؛ باستخدام اختبار ليفين(Levene Statistic) وجاءت النتائج كما في الجدول التالي:

جدول (17): اختبارليفين (Levene Statistic) لمتغير عدد سنوات الخدمة

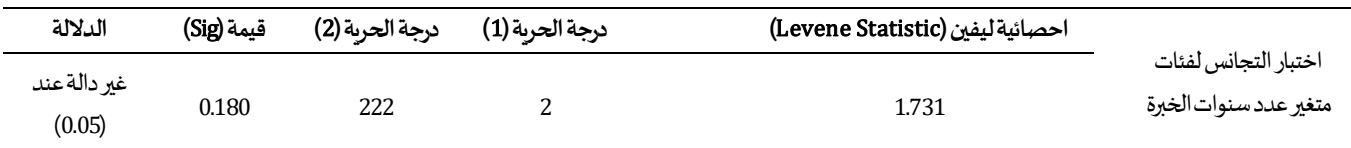

يتضح من الجدول (17) أن قيمة اختبار ليفين لتجانس فئات متغير عدد سنوات الخدمة كانت غير دالة إحصائيًا على وجود فروق في تجانس العينات الثلاث عند

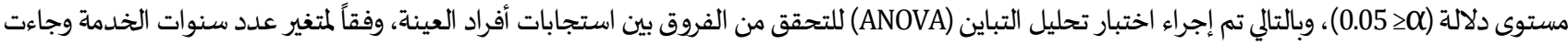
النتائج كما في الجدول دلالته

جدول (18): تحليل التباين (ANOVA) للفروق وفقًا لمتغيرعدد سنوات الخدمة

\begin{tabular}{|c|c|c|c|c|c|c|}
\hline مستوى & قيمة "ف" & متوسط المربعات & الحربة & مجموع المربعات & مصبدر التباين & المحاور \\
\hline \multirow{2}{*}{0.001} & \multirow{2}{*}{$7.464^{* *}$} & 255.685 & 2 & 511.371 & بين المجموعات & \multirow{2}{*}{ الطلبة } \\
\hline & & 34.258 & 222 & 7605.269 & داخل المجموعات & \\
\hline \multirow{2}{*}{0.017} & \multirow{2}{*}{$4.133^{* *}$} & 77.095 & 2 & 154.191 & بين المجموعات & \multirow{2}{*}{ المعلمون } \\
\hline & & 18.654 & 222 & 4141.169 & داخل المجمموعات & \\
\hline \multirow{2}{*}{0.150} & \multirow{2}{*}{1.911} & 23.482 & 2 & 46.963 & بين المجموعات & \multirow[t]{2}{*}{ الأنشطة المدرسية } \\
\hline & & 12.287 & 222 & 2727.677 & داخل المجموعات & \\
\hline \multirow{2}{*}{0.129 . } & \multirow{2}{*}{2.066} & 32.565 & 2 & 65.129 & بين المجموعات & \multirow{2}{*}{ 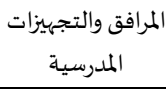 } \\
\hline & & 15.760 & 222 & 3498.631 & داخل المجموعات & \\
\hline \multirow{2}{*}{0.142} & \multirow{2}{*}{1.945} & 17.334 & 2 & 34.668 & بين المجموعات & \multirow{2}{*}{ التقويم والتنظيم } \\
\hline & & 8.911 & 222 & 1978.292 & داخل المجموعات & \\
\hline \multirow{2}{*}{0.26} & \multirow{2}{*}{$3.710^{* *}$} & 60.655 & 2 & 121.309 & بين المجموعات & \multirow{2}{*}{ المجتمع المحلي } \\
\hline & & 16.350 & 222 & 3629.731 & داخل المجمموعات & \\
\hline
\end{tabular}

يتضح من الجدول(18) أن قيمة (ف) للفروق بين استجابات أفراد عينة الدراسة حول درجة ممارسة القيادة المدرسية لأدوارهافي رعاية الطلبة الموهوبين بمحافظة

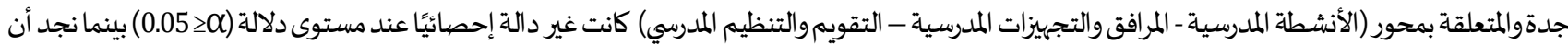
هناك فروقًا في استجابات عينة الدراسة حول درجة ممارسة القيادة المدرسية لأدوارها في رعاية الطلبة الموهوبين بمحافظة جدة والمتعلقة بـ محور (الطلبة- المعلمين -

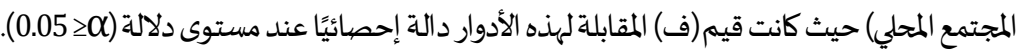
ولمعرفة اتجاه الفروق بين متوسطات استجابات عينة الدراسة حول درجة ممارسة القيادة المدرسية لأدوارها في رعاية الطلبة الموهوبين بمحافظة جدة

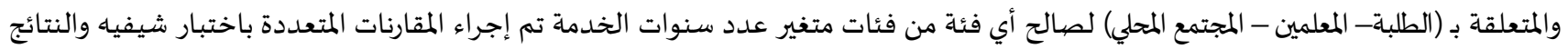

جدول (19): اختبارشيفيه لدلالة الفروق تبعًا لمتغير عدد سنوات الخدمة موضحة في الجدول (19) الآتي:

\begin{tabular}{|c|c|c|c|c|}
\hline مستوى الدلالة & الفرق يين المتوسطين & & 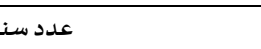 & المحور \\
\hline .001 & $-5.83333\left(\left(^{*}\right)\right.$ & من 5 إلى أقل من 10 سنوات & \multirow{2}{*}{ أقل من 5 سنوات } & \multirow{6}{*}{ الطلبة } \\
\hline .007 & $-4.73077(*)$ & من 10سنوات فأكثر & & \\
\hline .001 & $5.83333(*)$ & أقل من 5 سنوات & \multirow{2}{*}{ من 5 إلى أقل من 10 سنوات } & \\
\hline .407 & 1.10256 & من 10سنوات فأكثر & & \\
\hline .007 & $4.73077\left(^{*}\right)$ & أقل من 5 سنوات & \multirow{2}{*}{ من 10سنوات فأكثر } & \\
\hline .407 & -1.10256 & من 5 إلى أقل من 10 سنوات & & \\
\hline
\end{tabular}




\begin{tabular}{|c|c|c|c|c|}
\hline .018 & $-3.20000\left(^{*}\right)$ & من 5 إلى أقل من 10 سنوات & \multirow{4}{*}{ من 5 إلى أقل من 10 سنوات } & \multirow{6}{*}{ المعلمون } \\
\hline .042 & $-2.76923(*)$ & من 10سنوات فأكثر & & \\
\hline .018 & $3.20000\left(^{*}\right)$ & أقل من 5 سنوات & & \\
\hline .777 & .43077 & من 10سنوات فأكثر & & \\
\hline .042 & $2.76923\left(^{*}\right)$ & أقل من 5 سنوات & \multirow{2}{*}{ من 10سنوات فأكثر } & \\
\hline .777 & -.43077 & من 5 إلى أقل من 10 سنوات & & \\
\hline .027 & $-2.83333(*)$ & من 5 إلى أقل من 10 سنوات & \multirow{2}{*}{ أقل من 5 سنوات } & \multirow{6}{*}{ المجتمع المحلي } \\
\hline .054 & -2.48718 & من 10سنوات فأكثر & & \\
\hline .027 & $2.83333\left({ }^{*}\right)$ & أقل من 5 سنوات & \multirow{2}{*}{ من 5 إلى أقل من 10 سنوات } & \\
\hline .830 & .34615 & من 10سنوات فأكثر & & \\
\hline .054 & 2.48718 & أقل من 5 سنوات & \multirow{2}{*}{ من 10سنوات فأكثر } & \\
\hline .830 & -.34615 & من 5 إلى أقل من 10 سنوات & & \\
\hline
\end{tabular}

يتضح من الجدول (19) أن المقارنات بين متوسطات استجابات عينة الدراسة حول درجة ممارسة القيادة المدرسية لأدوارها في رعاية الطلبة الموهوبين بمحافظة

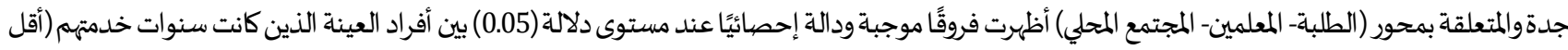

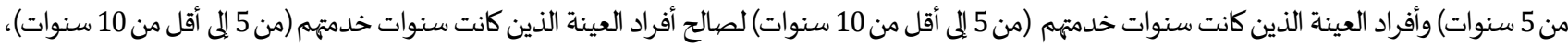

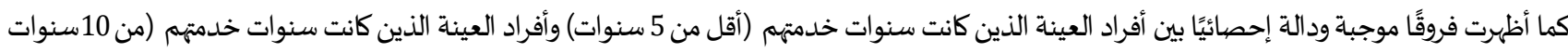

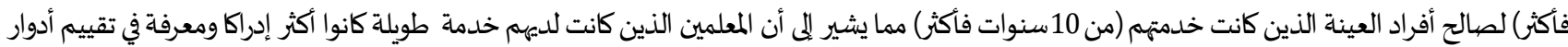
القيادة المدرسية في رعاية الطلبة الموهوبين والمتعلقة بمحور (الطلبة- المعلمين- المجتمع المحلي) .

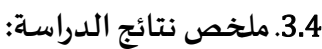
يمكن تلخيص أهم نتائج الدراسة في الآتي:

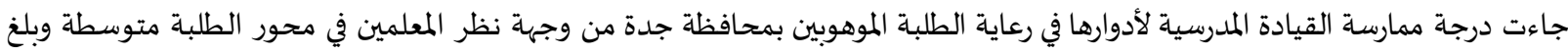
المتوسط العام للمحور (2.71).

جاءت درجة ممارسة القيادة المدرسية لأدوارها في رعاية الطلبة الموهوبين بمحافظة جدة من وجهة نظر المعلمين في محور المعلمين متوسطة وبلغ المتوسط العام للمحور (2.80). جاءت درجة ممارسة القيادة المدرسية لأدوارها في رعاية الطلبة الموهوبين بمحافظة جدة من وجهة نظر المملمين في محور الأنشطة المدرسية متوسطة وبلغ المتوسط العام للمحور (2.67). جاءت درجة ممارسة القيادة المدرسية لأدوارها في رعاية الطلبة الموهوبين بمحافظة جدة من وجهة نظر المعلمين في محور المرافق والتجهيزات المدرسية منخفضاة وبلغ المتوسط العام للمحور (2.48). جاءت درجة ممارسة القيادة المدرسية لأدوارها في رعاية الطلبة الموهوبين بمحافظة جدة من وجهة نظر المعلمين في محور التقويم والتنظيم المدرسي متوسطة وبلغ المتوسط العام للمحور (2.67). جاءت درجة ممارسة القيادة المدرسية لأدوارها في رعاية الطلبة الموهوبين بمحافظة جدة من وجهة نظر المعلمين في محور المجتمع المحلي متوسطة وبلغ المتوسط العام للمحور (2.68). أظهرت نتائج الدراسة وجود فروق دالة إحصائيًا في استجابات عينة الدراسة في محور (الطلبة- المعلمين- الأنشطة المدرسية - المرافق والتجهيزات المدرسية -

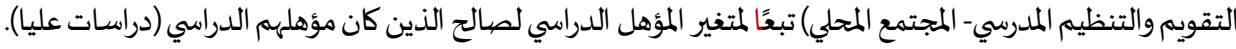
أظهرت نتائج الدراسة عدم وجود فروق دالة إحصائيًا في استجابات عينة الدراسة في محور (الطلبة- المعلمين- الأنشطة المدرسية-المرافق والتجهيزات

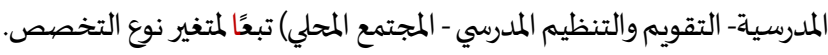
أظهرت نتائج الدراسة وجود فروق دالة إحصائيًا في استجابات عينة الدراسة في محور (الطلبة- المعلمين- الأنشطة المدرسية- المرافق والتجهيزات الماتمدرسية-

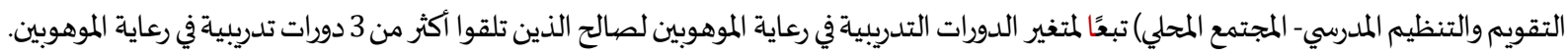
أظهرت نتائج الدراسة عدم وجود فروق دالة إحصائيًا في استجابات عينة الدراسة في محور (الطلبة- المعلمين) وفقًا لمتغير المرحلة المرابية المراسية. أظهرت نتائج الدراسة وجود فروق دالة إحصائيًا في استجابات عينة الدراسة في محور (الأنشطة المدرسية- المرافق والتجهيزات المدرسية- التقويم والتنظيم

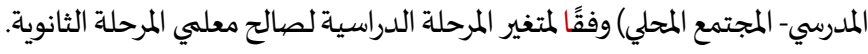


بناءً على النتائج الميدانية للدراسة يوصى الباحثان بالآتي: توفير مصادر مالية تتيح لقائد المدرسة تقديم بعض الحوافز المادية التي تسهم في رفع مستويات رضا المعلمين، وزيادة دافعيتهموبالتالي رفع مستويات أدائهم والذي بلدوره يسهم في رعاية الطلبة الموهوبين.

أن تعمل قيادة المدرسة على تنظيم وتنفيذ بعض الزيارات العلمية التي تسهم في إثراء خبرات ومعارف الطلبة الموهوبين. أن تحرص القيادة المدرسية على التعامل مع المعلمين بموضوعية وشفافية، وأن يعملوا على تحقيق العدالة التعليمية بكافة أشكالها مع المعلمين. أن تعمل القيادة المدرسية على وضع خطة للتنمية المهنية للمعلمين وفق احتياجاتهم. العمل على تفعيل الأنشطة والبرامج الحديثة الخاصة برعاية الموهوبين من خلال التواصل مع الجهات والأفراد ذات العلاقة. استقطاب القيادة المدرسية للمعلمين الأكفاء للعمل بمدارس الموهوبين، وتوفيز البيئة الملائمة لإبداع هؤلاء المعلمين للقيام بدورهم في رعاية الطلبة الموهوبين على أكمل وجها. تنظيم لقاءات دورية مع أولياء الأمور من قبل قائد المدرسة بغرض تحقيق سُبل التكامل في رعاية الموهبة والإبداع.

1. البدري، طارق عبد الحميد (2002). أساسيات الإدارة التعليمية ومناهجها. دار الفكر للطباعة والنشروالتوزيع. 2. البريك، سالم محمد (2010). نماذج تلدريسية في تعليم الموهوبين. دار النشر المغربية.

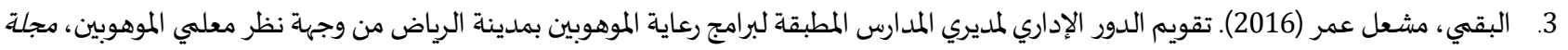
جامعة الفيوم للعلوم التربوية والنفسية: 2 (6): 107-148. 4. تنيرة، حمدي خليل (2016). دور الإدارة المدرسية في اكتشاف الموهوبين ورعاية الطلبة الموهوبين وعلاقتها بممارسة النشاطات الطابلابية بمدارس الأونروا من وجهة نظر المعلمين [رسالة ماجستير غير منشورة]. كلية التربية، جامعة الأزهر بغزة. 5. جروان، فتحي عبد الرحمن ( 2013). أساليب الكثشف عن الموهوبين والمتفوقين ورعايتهم. مكتبة دار القلم.

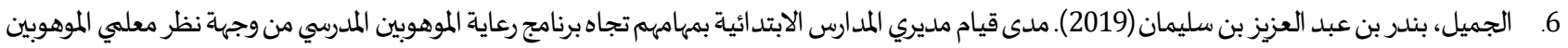

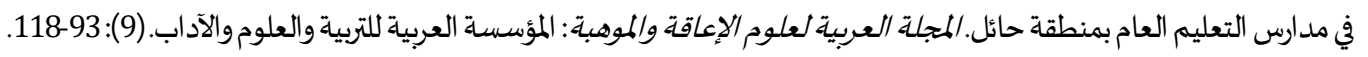

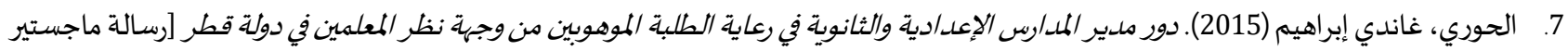

غير منشورة]. كلية العلوم التربوية، جامعة الشرق الأوسط. 8. الد اعور، سعيد خضر (2007). دور قائد الممرسة الثانوية كقائد تربوي في محافظات غنة وعاتلاقتاه بالثقافة التنظيمية للمدرسة من وجهة نظر المعلمين [رسالة ماجستير غير منشورة]. الجامعة الإسلامية بغزة.

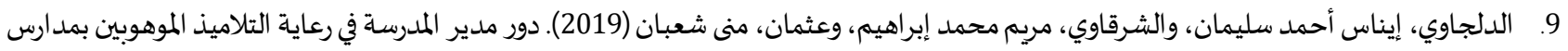
التعليم الأساسي، مجلة جامعة الفيوم للعلوم التبوية والنفسية: كلية التربية، جامعة الفيوم، $2(12): 138-99$.

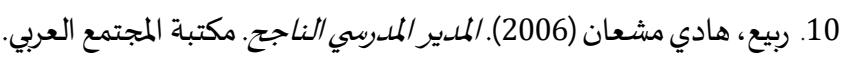
11. الزامل، سند عبد الله (2014). بوصلاة المعلمز في ميدان تربية الموهوبين. مكتبة ابن تيمية للنشر.

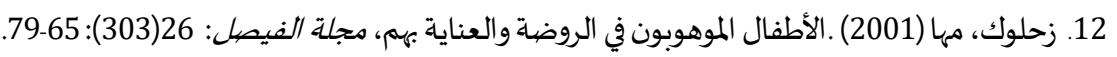
13. السدة، هشام أحمد (2012). مراكز رعاية الموهوبين في العالم الإسلامي. مطبعة الهلال.

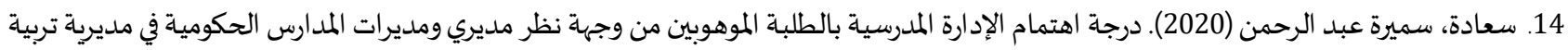

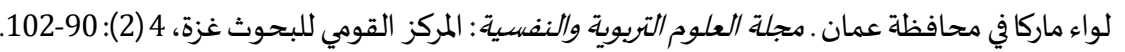

15. شقير، زينب محمود (1998). رعاية المتفوقين والموهوبين والمبدعين. مكتبة النهضية المصرية.

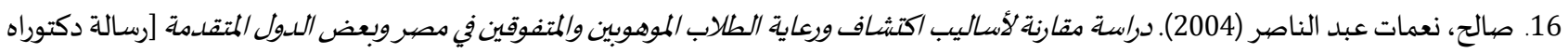

غير منشورة].كلية التربية جامعة عين شمس.

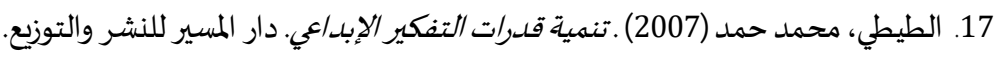
18. العاجز، فؤاد على؛ ومرتجي، زكي رمزي (2012).واقع الطلبة الموهوبين والمتفوقين بمحافظة غزة وسبل تحسينه. مجلة الجامعة الإسلامية للسراسات التوبوية

19. عبد الغفار، أحلام (2003). الرعاية التويوية للمتفوقين دراسيًا . دار الفجر للنشر والتوزيع. 
20. العبد الله، عادل محمد (2010). رعاية الموهوبين: إشاد/ت للآباء والمعلمين. مكتبة ابن تيمية للنشر.

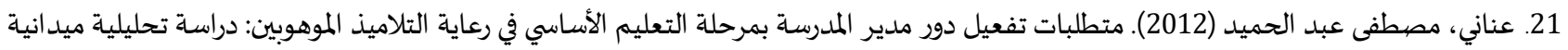

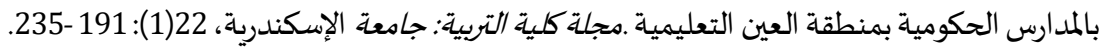

22. كشموله، عمر محمد صبتي (2007).تأثير النمط القيادي في بناء القدرات الإستراتيجية للمنظمة [رسالة ماجستير غير منشورة] كلية الإدارة والاقتصاد، المادية

$$
\text { جامعة الموصل. }
$$

23. محممد، منال محروس عبد الحميد (2019). واقع اكتشاف ورعاية التلاميذ الموهوبين في مدارس التعليم العام بالمملكة العربية السعودية من وجهة نظر

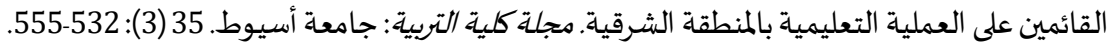

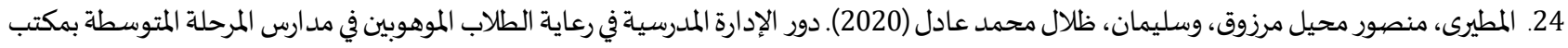

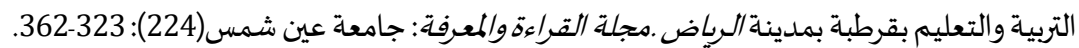

25. المنيع، عثمان بن محمد، والقرشى، خالد بن مطر عيد (2017). تطوير الأنشطة الاجتماعية والثقافية لرعاية الطلاب الموهوبين في المرحلة الثانوية في ضوء

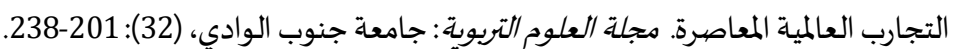

26. موسى، نجيب موسى (2003). أساليب المعاملة الوالدية للأطفال الموهوبين [رسالة ماجستير منشورة]. كلية العلوم الاجتماعية، جامعة حلوانهان.

$$
\text { 27. موسى، نجيب موسى (2013) . رعاية الأطفال الموهوبين. مركز الكتاب الأكاديمي. }
$$

28. أبو ناصر، فتحي محمد (2014). درجة ممارسة مديري المدارس الحكومية لإد ارة البرامج والأنشطة المدرسية المتعلقة بالموهوبين في المنطقة الشرقياة، مجلة

العلوم التتبوية: جامعة الملك سعود، 62 (1): 161 - 182.

29. الهاشي، محمد بن فيصل (2014). الأساليب العلمية لرعاية الموهوبين في الوطن العبلي. مكتبة الأنجلو المصرية.

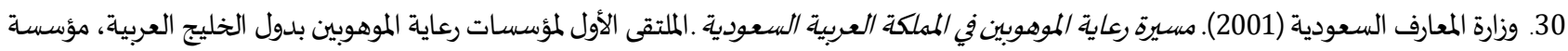

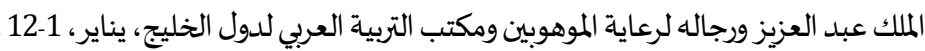

ثانياً: المراجع الأجنبية:

1. Kirsi, T., \& Elina, K. (2013). How Finland Serves Gifted and Talented Pupils. Journal for the Education of the Gifted. 36(1) 84-96. https://doi.org/10.1177/0162353212468066

2. Manhal, M .(2009). The Controlling and the Performance Appraisal. Sayyab book, London.

3. Martinez, A., \& Nicolas, B. (2017). Finding Albert Einstein, Detecting and strengthening talents in Chilean Education, Thesis for the Academic Degree of Bachelor of Education, Universidad Mayor. 


$$
\text { المجلة الدولية للدراسـات التربوية والنفسية }
$$

International Journal of Educational \& Psychological Studies (EPS)

Journal Homepage: https://www.refaad.com/views/EPSR/Home.aspx

www.refaad.com

ISSN: 2520-4149 (Online) 2520-4130 (Print)

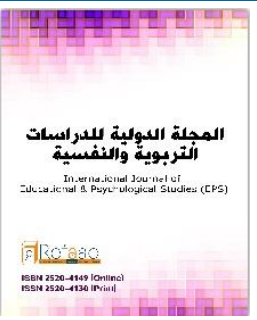

\title{
The degree of school leadership practice of its role in caring for gifted students at Jeddah governorate
}

\author{
Mohammed Ahmed Alshehri \\ Alfaisalyah School for Gifted, KSA \\ Abolama766@gmail.com
}

Fahad Abdulrahman Almalki

Associate Professor, College of Education, University of Jeddah, KSA

\author{
Received : 7/5/2021 Revised:17/5/2021 Accepted : 22/7/2021 DOI : https://doi.org/10.31559/EPS2021.10.2.13
}

Abstract: The purpose of the study was to investigate the degree of school leadership practicing its role in taking care of gifted students as perceived by teachers. The study adopted the survey descriptive approach, as the questionnaire was used to collect data. The population of the study consisted of all teachers in gifted schools at Jeddah governorate in the schooling year 1441/1442 H, a sample of (225) teachers was selected randomly and responded to a questionnaire consisted of (45) items distributed into eight domains. The findings of the study showed that The school leadership practice of its roles in caring for gifted students in the domains of students - teachers - school activities - evaluation and school organization - and the local community was in an average degree; as well as the degree of school leadership's practice of its roles in caring for gifted students in the domains of school facilities and equipment was low. There are significant statistical differences according to the academic qualification variable, in favor of those whose academic qualification was (postgraduate), there are no significant statistical differences according to the type of specialization, there are significant statistical differences according training courses variable in the care of the gifted, in favor of those who received more than 3 training courses. There are significant statistical differences according to school stage variable, in (school activities - school facilities and equipment - school calendar and organization - the local community) domains in favor of secondary school teachers.

Keywords: School leadership; Gifted Students; Practice.

\section{References:}

1. Al'ajz, F'ad 'la: Wmrtjy, Zky Rmzy (2012). Waq' Altlbh Almwhwbyn Walmtfwqyn Bmhafzt Ghzh Wsbl Thsynh. Mjlt Aljam'h Aleslamyh Lldrasat Altrbwyh Walnfsyh: 20 (1): 333-367.

2. 'bd Alghfar, Ahlam (2003 .(Alr'ayh Altrbwyh Llmtfwqyn Drasyana. Dar Alfjr Llnshr Waltwzy'.

3. Al'bd Allh, 'adl Mhmd (2010). R'ayt Almwhwbyn: Ershadat Llaba' Walm'lmyn. Mktbt Abn Tymyt Llnshr.

4. ' 'nany, Mstfa 'Ebd Alhmyd (2012). Mttlbat Tf'yl Dwr Mdyr Almdrsh Bmrhlh Alt'lym Alasasy Fy R'ayt Altlamyd Almwhwbyn: Drash Thlylyh Mydanyh Balmdars Alhkwmyh Bmntqh Al'yn Alt'lymyh. Mjlh Klyh Altrbyh: Jam't Aleskndryh, $22(1): 191$ 235.

5. Albdry, Tarq 'bd Alhmyd (2002). Asasyat Aledarh Alt'lymyh Wmnahjha. Dar Alfkr Lltba'h Walnshr Waltwzy'.

6. Albryk, Salm Mhmd (2010). Nmadj Tdrysyh Fy T'lym Almwhwbyn. Dar Alnshr Almghrbyh.

7. Albqmy, Msh'l 'mr (2016). Tqwym Aldwr Aledary Lmdyry Almdars Almtbqh Lbramj R'ayt Almwhwbyn Bmdynt Alryad Mn Wjht Nzr M'Imy Almwhwbyn, Mjlh Jam't Alfywm Ll'lwm Altrbwyh Walnfsyh: 2 (6): 107-148.

8. Alda'wr, S'eyd Khdr (2007). Dwr Qa'd Almdrsh Althanwyh Kqa'd Trbwy Fy Mhafzat Ghzh W'laqth Balthqafh Altnzymyh Llmdrsh Mn Wjht Nzr Alm'lmyn [Rsalt Majstyr Ghyr Mnshwrh]. Aljam'h Aleslamyh Bghzh.

9. Aldljawy, Eynas Ahmd Slyman, Walshrqawy, Mrym Mhmd Ebrahym, W'thman, Mna Sh'ban (2019). Dwr Mdyr Almdrsh Fy R'ayt Altlamyd Almwhwbyn Bmdars Alt'lym Alasasy, Mjlt Jam't Alfywm Ll'lwm Altrbwyh Walnfsyh: Klyt Altrbyh, Jam't Alfywm, 2(12): 99-138. 
10. Alhashmy, Mhmd Bn Fysl (2014). Alasalyb Al'lmyh Lr'ayh Almwhwbyn Fy Alwtn Al'rby. Mktbt Alanjlw Almsryh.

11. Alhwry, Ghandy Ebrahym (2015). Dwr Mdyr Almdars Ale'dadyh Walthanwyh Fy R'ayt Altlbh Almwhwbyn Mn Wjht Nzr Alm'lmyn Fy Dwlt Qtr [Rsalt Majstyr Ghyr Mnshwrh]. Klyt Al'lwm Altrbwyh, Jam't Alshrq Alawst.

12. Aljmyl, Bndr Bn 'bd Al'zyz Bn Slyman (2019). Mda Qyam Mdyry Almdars Alabtda'yh Bmhamhm Tjah Brnamj R'ayt Almwhwbyn Almdrsy Mn Wjht Nzr M'Imy Almwhwbyn Fy Mdars Alt'lym Al'am Bmntqh Ha'l. Almjlh Al'rbyh L'lwm Ale'aqh Walmwhbh: Alm'ssh Al'rbyh Lltrbyh Wal'lwm Waladab. (9): 93-118.

13. Jrwan, Fthy 'bd Alrhmn (2013). Asalyb Alkshf 'n Almwhwbyn Walmtfwqyn Wr'aythm. Mktbt Dar Alqlm.

14. Kshmwlh, 'mr Mhmd Sbhy (2007). Tathyr Alnmt Alqyady Fy Bna' Alqdrat Alestratyjyh Llmnzmh [Rsalt Majstyr Ghyr Mnshwrh] Klyt Aledarh Walaqtsad, Jam't Almwsl.

15. Mhmd, Mnal Mhrws 'bd Alhmyd (2019). Waq' Aktshaf Wr'ayt Altlamyd Almwhwbyn Fy Mdars Alt'lym Al'am Balmmlkh Al'rbyh Als'wdyh Mn Wjht Nzr Alqa'myn 'la Al'mlyh Alt'lymyh Balmntqh Alshrqyh. Mjlt Klyt Altrbyh: Jam't Asywt. 35 (3): 532-555.

16. Almny', 'thman Bn Mhmd, Walqrsha, Khald Bn Mtr 'yd (2017). Ttwyr Alanshth Alajtma'yh Walthqafyh Lr'ayh Altlab Almwhwbyn Fy Almrhlh Althanwyh Fy Dw' Altjarb Al'almyh Alm'asrh. Mjlt Al'lwm Altrbwyh: Jam't Jnwb Alwady, (32): 201-238.

17. Almtyra, Mnswr Mhyl Mrzwq, Wslyman, Zlal Mhmd 'adl (2020). Dwr Aledarh Almdrsyh Fy R'ayt Altlab Almwhwbyn Fy Mdars Almrhlh Almtwsth Bmktb Altrbyh Walt'lym Bqrtbh Bmdynh Alryad. Mjlt Alqra'h Walm'rfh: Jam't 'yn Shms(224): 323-362.

18. Mwsa, Njyb Mwsa (2003). Asalyb Alm'amlh Alwaldyh Llatfal Almwhwbyn [Rsalt Majstyr Mnshwrh]. Klyt Al'lwm Alajtma'yh, Jam't Hlwan.

19. Mwsa, Njyb Mwsa (2013). R'ayt Alatfal Almwhwbyn. Mrkz Alktab Alakadymy.

20. Abw Nasr, Fthy Mhmd (2014). Drjt Mmarsh Mdyry Almdars Alhkwmyh Ledarh Albramj Walanshth Almdrsyh Almt'lqh Balmwhwbyn Fy Almntqh Alshrqyh, Mjlt Al'lwm Altrbwyh: Jam't Almlk S'ewd, 62 (1): 161 - 182.

21. Rby', Hady Msh'an (2006). Almdyr Almdrsy Alnajh. Mktbt Almjtm' Al'rby.

22. S'adh, Smyrh 'Ebd Alrhmn (2020). Drjt Ahtmam Aledarh Almdrsyh Baltlbh Almwhwbyn Mn Wjht Nzr Mdyry Wmdyrat Almdars Alhkwmyh Fy Mdyryh Trbyh Lwa' Marka Fy Mhafzt 'man. Mjlt Al'lwm Altrbwyh Walnfsyh: Almrkz Alqwmy Llbhwth Ghzh, 4 (2): 90-102.

23. Salh, N'mat 'bd Alnasr (2004). Drash Mqarnh Lasalyb Aktshaf Wr'ayh Altlab Almwhwbyn Walmtfwqyn Fy Msr Wb'd Aldwl Almtqdmh [Rsalt Dktwrah Ghyr Mnshwrh]. Klyt Altrbyh Jam't 'yn Shms.

24. Alsdh, Hsham Ahmd (2012). Mrakz R'ayt Almwhwbyn Fy Al'alm Aleslamy. Mtb't Alhlal.

25. Shqyr, Zynb Mhmwd (1998). R'ayt Almtfwqyn Walmwhwbyn Walmbd'yn. Mktbt Alnhdh Almsryh.

26. Tnyrh, Hmdy Khlyl (2016). Dwr Aledarh Almdrsyh Fy Aktshaf Almwhwbyn Wr'ayh Altlbh Almwhwbyn W'laqtha Bmmarsh Alnshatat Altlabyh Bmdars Alawnrwa Mn Wjht Nzr Alm'lmyn [Rsalh Majstyr Ghyr Mnshwrh]. Klyt Altrbyh, Jam't Alazhr Bghzh.

27. Altyty, Mhmd Hmd (2007). Tnmyt Qdrat Altfkyr Alebda'y. Dar Almsyr Llnshr Waltwzy'.

28. Wzart Alm'arf Als'ewdyh (2001). Msyrh R'ayt Almwhwbyn Fy Almmlkh Al'rbyh Als'wdyh. Almltqa Alawl Lm'ssat R'ayt Almwhwbyn Bdwl Alkhlyj Al'rbyh, M'sst Almlk 'bd Al'zyz Wrjalt Lr'ayh Almwhwbyn Wmktb Altrbyh Al'rby Ldwl Alkhlyj, Ynayr, 1-12.

29. Alzaml, Snd 'bd Allh (2014). Bwslh Alm'lm: Fy Mydan Trbyt Almwhwbyn. Mktbt Abn Tymyh Llnshr.

30. Zhlwk, Mha (2001). Alatfal Almwhwbwn Fy Alrwdh Wal'nayh Bhm, Mjlt Alfysl: 26(303): 65-79. 